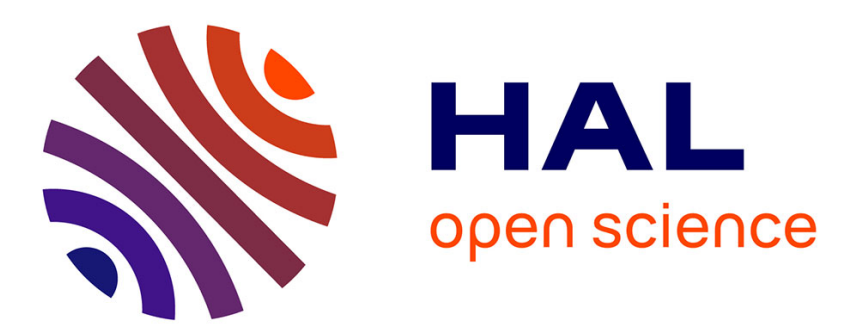

\title{
Chemically Induced Breathing of Flexible Porphyrinic Covalent Cages
}

Laëtitia Schoepff, Lucas Kocher, Stephanie Durot, Valerie Heitz

\section{To cite this version:}

Laëtitia Schoepff, Lucas Kocher, Stephanie Durot, Valerie Heitz. Chemically Induced Breathing of Flexible Porphyrinic Covalent Cages. Journal of Organic Chemistry, 2017, 82 (11), pp.5845-5851. 10.1021/acs.joc.7b00698 . hal-03238107

\section{HAL Id: hal-03238107 https://hal.science/hal-03238107}

Submitted on 26 May 2021

HAL is a multi-disciplinary open access archive for the deposit and dissemination of scientific research documents, whether they are published or not. The documents may come from teaching and research institutions in France or abroad, or from public or private research centers.
L'archive ouverte pluridisciplinaire HAL, est destinée au dépôt et à la diffusion de documents scientifiques de niveau recherche, publiés ou non, émanant des établissements d'enseignement et de recherche français ou étrangers, des laboratoires publics ou privés. 


\title{
Chemically-induced breathing of flexible porphyrinic covalent cages
}

\author{
Laetitia Schoepff, Lucas Kocher, Stéphanie Durot* and Valérie Heitz*
}

Laboratoire de Synthèse des Assemblages Moléculaires Multifonctionnels, Institut de Chimie de Strasbourg, CNRS/UMR

7177, Université de Strasbourg, 4, rue Blaise Pascal, 67000 Strasbourg, France.

\begin{abstract}
The synthesis of two flexible bis-porphyrin cages $\mathbf{3}$ and 4, incorporating respectively Zn(II) porphyrins and free-base porphyrins is reported. In both cages, the four covalent linkers that bind the two porphyrins are functionalized with two 1,2,3triazolyl ligands. These cages were characterized by NMR and HRMS and for cage 3 incorporating 1,4-diazabicyclo[2.2.2] octane (DABCO), an X-ray crystallographic structure was obtained. Chemically-induced conformational changes are studied and compared to the ones of two related cages with longer flexible linkers. Binding of four silver(I) ions to the peripheral ligands opens the flattened structures in solution and locks the two porphyrins in a face-to-face disposition. Addition of an excess of acid fully expand the cages due to electrostatic repulsion between the positively charged sites. These two reversible processes allow for a chemicallyinduced breathing of the flexible structures.
\end{abstract}




\section{INTRODUCTION}

The construction of molecular containers, capsules or cage-like compounds represents an active field of research and many chemical tools, in terms of bond formation (covalent, coordination and hydrogen bonds) and synthesis pathway (self-assembly, templated synthesis, dynamic combinatorial chemistry) have been exploited, leading to 3D architectures of high diversity. ${ }^{1}$ As anticipated, these hollow structures were able to stabilize guest molecules according to their size, shape and affinity for the host. Isolated from the bulk solvent, the encapsulated guest modifies sometimes to a large extent its physical and chemical properties. Therefore, molecular encapsulation enables to stabilise reactive molecules or to perform chemical reactions inside molecular containers that behave as nanoreactors. ${ }^{2}$ One way to control the binding and delivery of the guest molecule or the release of the reaction product is to incorporate constituents in the nanocontainer structure that respond to an external stimulus by triggering a large conformational change that modifies the host encapsulation properties. Some results in this area were obtained with multicomponent structures using photonic, ${ }^{3}$ chemical $^{4}$ or redox signal.

In the large variety of molecular containers conceivable, the synthesis of covalent hollow structures incorporating several metalated or free-base porphyrins is attractive for the high chemical stability expected with covalent structures and for the aptitude of porphyrins to interact with various types of guest molecules through $\pi-\pi$ interactions or coordination bonds. ${ }^{6}$ Several improved synthetic procedures were recently reported to afford such compounds. ${ }^{7}$ Our aim was to synthesize covalent porphyrinic cages with additional active components in their structures. We have developed the synthesis of covalent cages consisting of two porphyrins connected by four flexible diethyleneglycol linkers 1-2, each incorporating two 1,2,3-triazolyl ligands (Scheme 1a). ${ }^{8}$ In such structures, silver(I) was used as a chemical stimulus the to control the cavity size. Herein, the DABCO-templated $\mathrm{Cu}(\mathrm{I})$ catalyzed azide-alkyne cycloaddition (CuAAC) reaction leading of the triisopropylsilyl (TIPS)-monoprotected alkyne 7 and using to molecular cage 3, characterized by shorter covalent linkers $\mathrm{CuSO}_{4}$ as catalyst led to porphyrin $\mathbf{8}$ in $89 \%$ yield (Scheme 2 b). between the zinc(II) porphyrins is reported. The synthesis of cage Classical removal of the TIPS protecting groups from porphyrin 4, incorporating two free-base porphyrins is also described. The 8 using tetrabutylammonium fluoride (TBAF) afforded 6 in $80 \%$ chemical induced conformational changes triggered by silver(I) yield. A mixture of three DABCO•porphyrin dimers was obcoordination to the peripheral triazoles or by protonation of the tained upon addition of 1 equiv of DABCO to a millimolar solufree-base porphyrins and the triazoles are investigated and com- tion of 5 and 6 in $\mathrm{CH}_{2} \mathrm{Cl}_{2}$ (Scheme $2 \mathrm{c}$ ). The four intramolecular pared to the ones occurring in cages 1-2 with longer spacers. CuAAC click reactions proceed only from the 5•DABCO•6 Addition of an acid allows for a greater expansion of cages $\mathbf{2}$ and hetero dimer, with $\left[\mathrm{Cu}\left(\operatorname{tren}^{\prime}\right)\right] \mathrm{Br}$ as catalyst ${ }^{10}$ to avoid the deco3 as compared to silver(I) complexation, due to the numerous ordination of DABCO. After 2 days of reaction, the crude was repulsive protonated sites. The NMR and DOSY experiments submitted to column chromatographies to remove polymers and provide evidence of the large size modifications of the flexible partially cyclized by-products. The cage including DABCO, covalent structures associated to these reversible chemical pro- 3.DABCO, was isolated as a purple solid in $46 \%$ yield. In anothcesses. a)

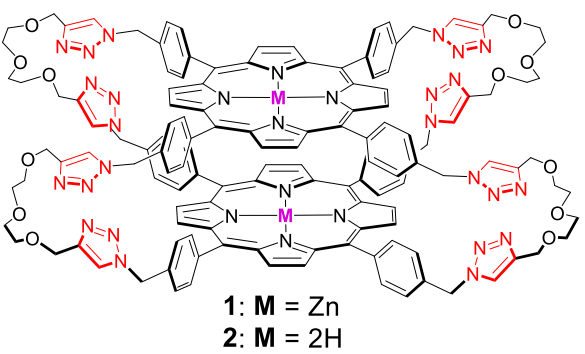

b)

Scheme 1. a) Cages 1-2 already reported. ${ }^{8}$ b) Cages 3-4 of the present study in which shorter linkers connect the porphyrins.

\section{RESULTS AND DISCUSSION}

The synthesis of cage 3 relies on a DABCO-templated CuAAC eaction from two porphyrinic precursors 5 and $\mathbf{6}$ (Scheme 2 a). The CuAAC reaction enables to introduce one triazolyl ligand in
each of the four bis-porphyrin linkers while proceeding to the yclisation reaction between the tetraazide-functionalized porphyrin 5 and the tetraalkyne-functionalized porphyrin $\mathbf{6}$. The two porphyrin precursors $5^{9}$ and 6 were prepared without difficulty at the hundred mg scale. A first CuAAC reaction performed in 3-DABCO, was isolated as a purple solid in $46 \%$ yield. In anoth-
er attempt to isolate 3 , the crude was treated with $\mathrm{HCl}$ to demetalate the porphyrins. Column chromatographies afforded cage $\mathbf{4}$ in $58 \%$ yield and subsequent metalation of the free-base porphyrins with 2 equiv of $\mathrm{Zn}(\mathrm{OAc})_{2} \cdot 2 \mathrm{H}_{2} \mathrm{O}$ gave 3 quantitatively. 
a)

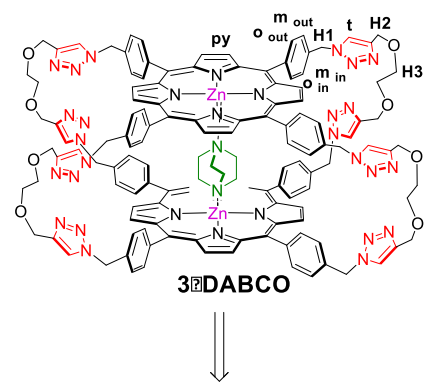

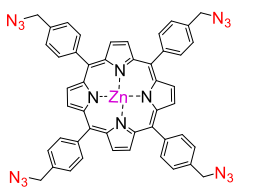

5

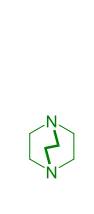

DABCO

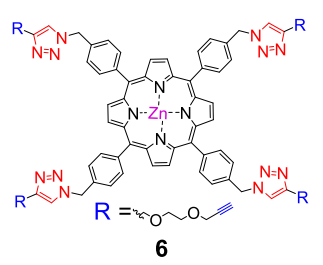

b)

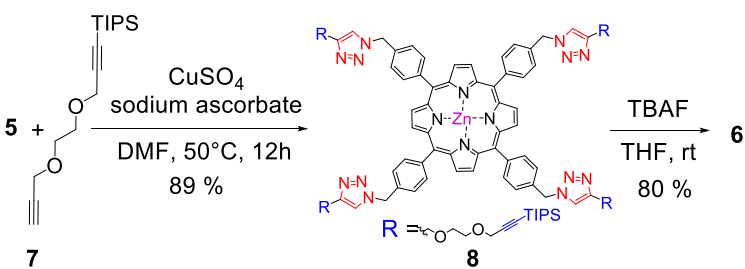

c)

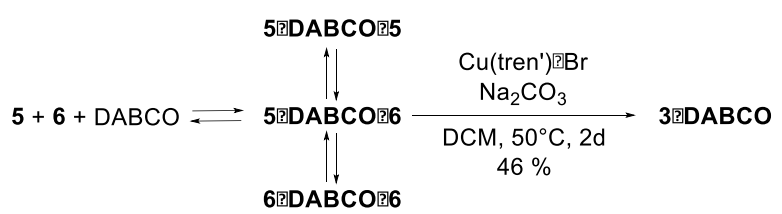

a)

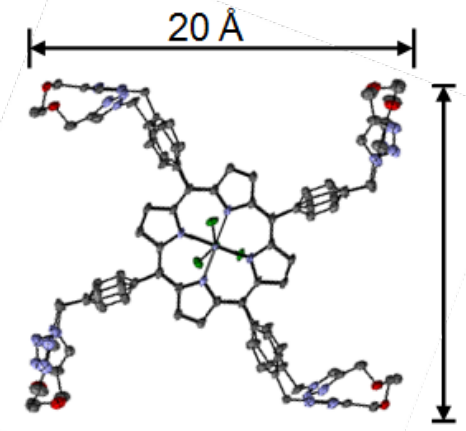

$18 \AA$

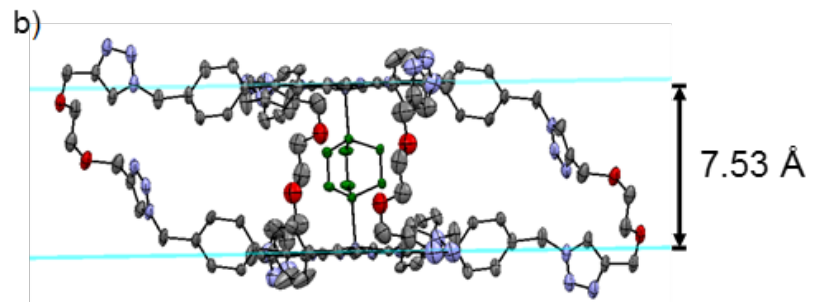

Figure 1. ORTEP representation of the molecular structure of the complex 3•DABCO. a) Top view and b) side view. ORTEP ellipsoids are set at $30 \%$ probability. $\mathrm{H}$ atoms and solvent molecules are omitted for clarity (Color code for the atoms: $\mathrm{C}$ grey, $\mathrm{N}$ blue, $\mathrm{O}$ red, $\mathrm{Zn}$ purple, DABCO green).

In solution, the ${ }^{1} \mathrm{H}$ NMR spectrum of $\mathbf{3} \cdot \mathbf{D A B C O}$ is also consistent with an eclipsed disposition of the porphyrins and an average structure of $C_{4}$ symmetry (Figure 2). DABCO coordinated to the zinc(II) porphyrins inside the cavity is affected by the strong ring current of the two porphyrins resulting in a high upfield shifted signal at $-4.67 \mathrm{ppm}$ for its twelve protons.

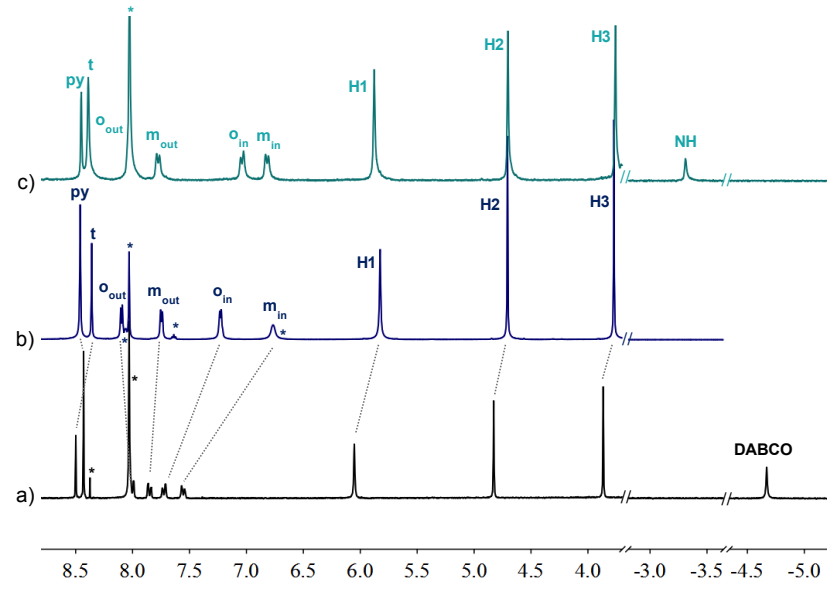

Scheme 2. a) DABCO-templated CuAAC strategy to obtain cage 3.DABCO. b) Synthesis of precursor 6. c) Synthesis of cages 3•DABCO, 4 and 3.

The DABCO-templated cyclisation reaction reported for cage $\mathbf{1}$ was performed in analogous conditions but afforded $\mathbf{1}$ in lower yield, $25 \%{ }^{8}$ The DABCO-preorganisation of the two porphyrin precursors is more effective in the present synthesis, due to the shorter linkers of precursor 6. Furthermore, DABCO is more stable in cage 3 and was not partially removed during purification by column chromatography, making the purification of 3•DABCO easier to handle.

Single crystals of 3•DABCO were obtained by slow diffusion Figure 2. ${ }^{1} \mathrm{H}$ NMR spectra in DMF- $d_{7}(298 \mathrm{~K})$ of a) 3•DABCO (400 of pentane into a chloroform solution of the $\mathbf{3} \cdot \mathbf{D A B C O}$ complex MHz), b) cage 3 (DMF- $d_{7}+2 \%$ pyridine- $d_{5}, 500 \mathrm{MHz}$ ), and c) cage (Figure 1). The already mentioned X-ray crystal structure of $4(300 \mathrm{MHz}) .{ }^{*}$ Residual solvents.

1.DABCO ${ }^{8}$ was of low quality but with other crystallization attempts and by using slow diffusion of acetone into a DMF solution of the complex, we managed to obtain a nice structure (SI Figure S87 and Table S3). The two structures 3•DABCO and 1-DABCO are similar, with two eclipsed $\mathrm{Zn}$ (II) porphyrins. The shorter linkers of $\mathbf{3}$ ensure enough flexibility to accommodate $\mathrm{DABCO}$ inside the cavity without distortion of the porphyrins and the $\mathrm{Zn}-\mathrm{N}$ bond length, $2.19 \AA$, is typical for this kind of complex. The mean planes of the porphyrins are separated by $7.53 \AA$, a distance close to the one measured in cage 1 -DABCO $(7.44 \AA)$

After removal of DABCO with an excess of pyridine, cage 3 was soluble in polar coordinating solvents like DMSO, $\mathrm{DMF} /$ pyridine $2 \%$ or in a mixture of $\mathrm{CHCl}_{3} / \mathrm{MeOH} /$ pyridine 9:1:0.5). In the ${ }^{1} \mathrm{H}$ NMR spectra recorded in either of these deuterated solvents, important upfield shifts of the aromatic protons $\mathrm{o}_{\text {in }}$ and $\mathrm{m}_{\mathrm{in}}$, pointing inside the cavity and less pronounced upfield shifts of protons $\mathrm{H} 1, \mathrm{H} 2$ and $\mathrm{H} 3$ of the linkers were noticed (Figure 2). They demonstrate a conformational change of the cage leading to a closer proximity of the porphyrins favoured by stabilizing $\pi-\pi$ interactions. Cage 4 incorporating free-base porphyrins displays chemical shifts close to the 
ones of cage 3 (Figure 2c), supporting a related flattened conformation for both cages as previously observed in solution for cages $\mathbf{1}$ and $\mathbf{2}$ and in the solid state for $\mathbf{1} .^{8}$

The modifications of the shape and position of the Soret absorption band of the zinc(II) porphyrins in cage $\mathbf{3}$ upon inclusion of the guest illustrated also the cage rearrangement. The initial very broad Soret band is consistent with electronic interactions between close porphyrins in the conformational free structure of 3 in solution (Figure 3). Upon DABCO binding, the porphyrins move away from each other in agreement with a thinning and bathochromic shift of the Soret band (Figure 3). The 1:1 binding constants $K$ of cages $\mathbf{1} \cdot \mathbf{D A B C O}$ and $\mathbf{3} \cdot \mathbf{D A B C O}$ were obtained by performing UV-visible titrations in $\mathrm{CHCl}_{3} / \mathrm{MeOH}(9: 1)$ since they were too high to be determined in $\mathrm{CHCl}_{3}$. The obtained association constant $K=1.3 \times 10^{7} \mathrm{M}^{-1}$ for 3•DABCO is $67 \%$ higher than the one of 1-DABCO, $K=7.8 \times 10^{6} \mathrm{M}^{-1}$ (SI Figures S85-86 and Table S2). This increased binding affinity can be attributed to the shorter linkers of cage $\mathbf{3}$ which insure a better preorganisation of the host structure for the guest molecule.
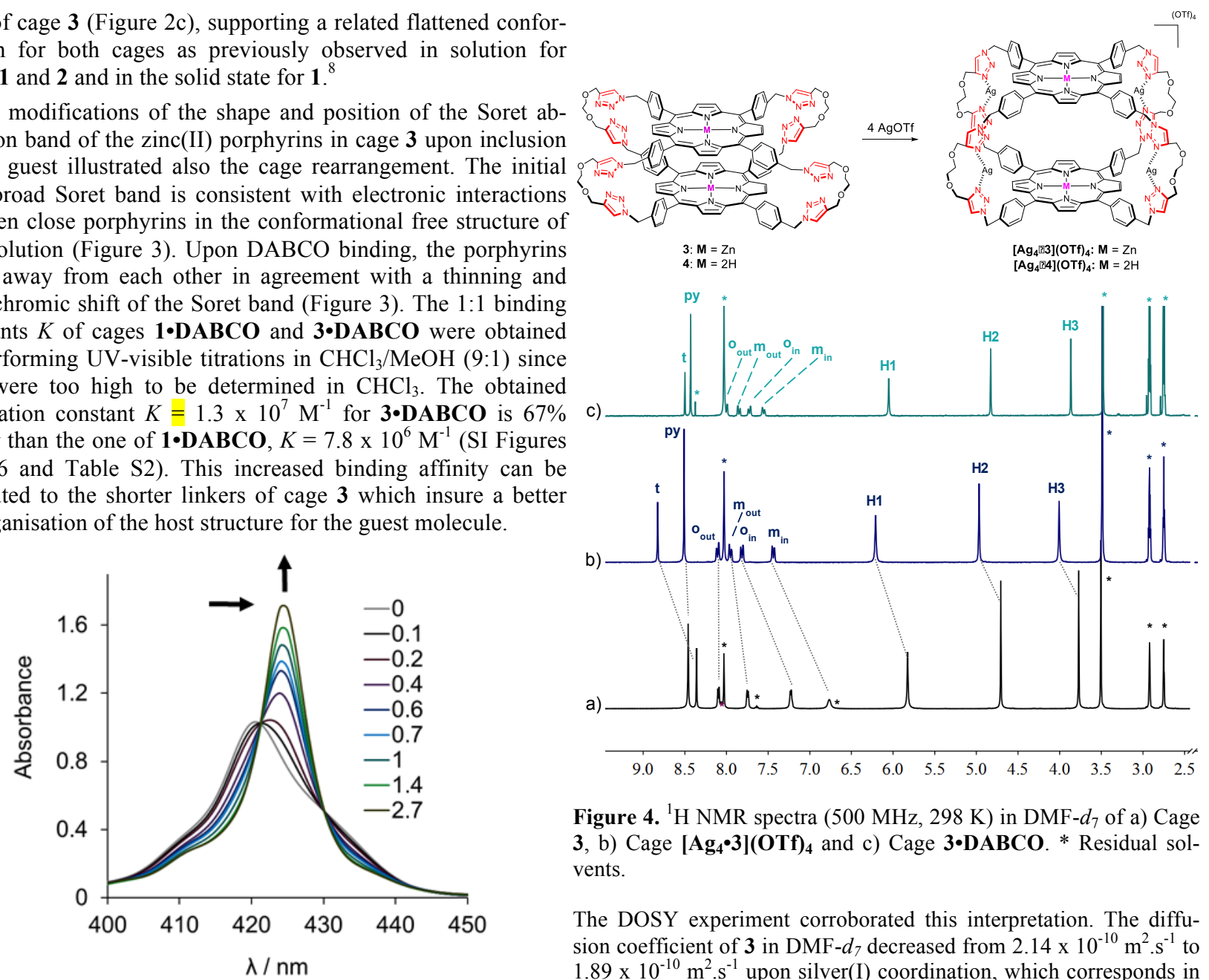

$\begin{array}{llllllllllllll}9.0 & 8.5 & 8.0 & 7.5 & 7.0 & 6.5 & 6.0 & 5.5 & 5.0 & 4.5 & 4.0 & 3.5 & 3.0 & 2.5\end{array}$

Figure 4. ${ }^{1} \mathrm{H}$ NMR spectra $(500 \mathrm{MHz}, 298 \mathrm{~K})$ in DMF- $d_{7}$ of a) Cage 3, b) Cage $\left[\mathbf{A g}_{4} \cdot \mathbf{3}\right](\mathbf{O T f})_{4}$ and c) Cage 3•DABCO. * Residual solvents.

The DOSY experiment corroborated this interpretation. The diffusion coefficient of 3 in DMF- $d_{7}$ decreased from $2.14 \times 10^{-10} \mathrm{~m}^{2} . \mathrm{s}^{-1}$ to $1.89 \times 10^{-10} \mathrm{~m}^{2} . \mathrm{s}^{-1}$ upon silver(I) coordination, which corresponds in Figure 3. UV-vis titration of 3 with DABCO in $\mathrm{CHCl}_{3} / \mathrm{MeOH}(9: 1)$.
The concentration of 3 was maintained constant at $1.2 \mu \mathrm{M}$. Number of equiv added: $0,0.1,0.2,0.4,0.6,0.7,1.0,1.4$ and 2.7 .

a spherical model ${ }^{11}$ to an increase of the hydrodynamic radius associated to the cage from $11.3 \AA$ to $12.8 \AA$. Cage $\mathbf{1}$ in its collapse conformation has a similar hydrodynamic radius of $10.9 \AA$, that also

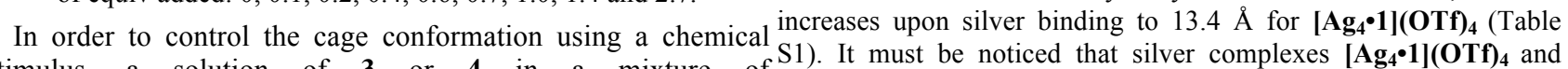
stimulus, a solution of $\mathbf{3}$ or $\mathbf{4}$ in a mixture of $\mathrm{S}_{\mathbf{1}}$. It must be noticed that silver complexes $\left.\mathbf{A g}_{\mathbf{4}} \mathbf{* 3}\right](\mathbf{O T f})_{\mathbf{4}}$ are very stable in presence of an excess of silver(I) $\mathrm{CH}_{2} \mathrm{Cl}_{2} / \mathrm{CHCl}_{3} / \mathrm{MeOH}$ (5:5:1) was reacted with four equiv of since no noticeable change occurred on the ${ }^{1} \mathrm{H}$ and DOSY NMR AgOTf. The red solid that precipitated readily was dissolved in spectra from 4 to 200 equiv of added silver(I) ion (SI Figures S44DMF and fully characterized by ${ }^{1} \mathrm{H}$ (COSY, NOESY, DOSY) 46 ). Solubilizing the silver cage $\left[\mathbf{A g}_{4} \mathbf{1}^{\mathbf{1}}\right]^{4+}$ or $\left[\mathbf{A g}_{4} \mathbf{A 3}^{\mathbf{4}}\right]^{\mathbf{H}^{+}}$in a solvent and ${ }^{13} \mathrm{C}$ NMR as well as HR-mass spectrometry. The high- of low polarity as DCM was possible by exchanging triflate with resolution mass spectrum attested the formation of the complex $\mathrm{BArF}^{-}$(BArF': tetrakis[3,5-bis(trifluoromethyl)phenyl]borate) aniwith a 4:1 silver/cage stoichiometry, with the detected ons. With $\mathrm{BArF}^{-}$as counter ion, the hydrodynamic radii of $\left[\mathbf{A g}_{\mathbf{4}} \cdot \mathbf{3}\right]^{\mathbf{4 +}} / 4$ peak at $\mathrm{m} / \mathrm{z}=693.0854$ whose isotopic profile was in $\left[\mathbf{A g}_{\mathbf{4}} \mathbf{\bullet} \mathbf{1}\right](\mathbf{B A r F})_{\mathbf{4}}$ and $\left[\mathbf{A g}_{\mathbf{4}} \cdot \mathbf{3}\right](\mathbf{B A r F})_{\mathbf{4}}$ were almost identical, $13.9 \AA$ accordance with the experimental ones. Another peak resulting and $13.8 \AA$ respectively. These results show that silver(I) coordinafrom the loss of one silver ion in the ESI experiment was also tion fixes the conformation of the flexible cages $\mathbf{1}$ and $\mathbf{3}$ with a codetected. Whereas silver(I) coordination did not modify the num- facial disposition of the porphyrins leading to very close hydrodyber of proton signals in agreement with a structure of high sym- namic radii. The same conclusions could be drawn from the DOSY metry, some important chemical shifts were observed on the ${ }^{1} \mathrm{H}$ results obtained when binding of silver(I) was performed on cages 2 NMR spectrum in DMF- $d_{7}$ (Figure 4). The downfield shift of and $\mathbf{4}$, which incorporate free-base porphyrins (SI Table S1). Such $0.47 \mathrm{ppm}$ of the triazole protons attested silver(I) binding to the metal-induced conformational changes are reversible and switching triazolyl ligands. The large downfield shifts of the aromatic pro- from the open silver-complexed cages back to the flattened confortons $\mathrm{o}_{\text {in }}(\Delta \delta=0.58 \mathrm{ppm})$ and $\mathrm{m}_{\text {in }}(\Delta \delta=0.67 \mathrm{ppm})$, as compared to mations could be easily achieved by removal of the silver(I) in presthe ones of $\mathrm{o}_{\text {out }}(\Delta \delta=0.01 \mathrm{ppm})$ and $\mathrm{m}_{\text {out }}(\Delta \delta=0.20 \mathrm{ppm})$ brings

them at chemical shifts close to the ones observed for 3•DABCO In order to enlarge the cavity size further than by coordinating (Figure 4c) where the zinc(II) porphyrins are about $7 \AA$ apart. silver(I) to the peripheral binding sites, protonation of the various These shifts indicate that silver(I) binding to the peripheral tria- basic sites was considered. Protonation of the eight triazoles and zoles opens the flattened cage 3 (Figure 4 ).

of the two free-base porphyrins of cages 2 and 4 , could lead to twelve positively charged species. Thanks to the flexible linkers, expansion of both cages is expected in response to strong electro- 
static repulsion. Cage 4 gave a green solution in $\mathrm{CD}_{2} \mathrm{Cl}_{2}$ upon addition of deuterated trifluoroacetic acid (TFA- $d$ ). Its ${ }^{1} \mathrm{H}$ NMR spectrum (Figure 5) attested that the two porphyrins are moving away from each other by the progressive downfield chemical a) shifts of the $\mathrm{o}_{\text {in }}$ and $\mathrm{m}_{\text {in }}$ aromatic protons. After addition of 24 equiv of TFA- $d$ (Figure 5b), all the signals are large, indicating slow exchange between partially protonated cages. In presence of a large excess of acid, the chemical shifts of the $o_{\text {in }}$ and $m_{\text {in }}$ protons were downfield shifted and closer to those of protons $\mathrm{o}_{\text {out }}$ and $\mathrm{m}_{\text {out }}$ (Figure $5 \mathrm{~d}$ ). The use of an excess of TFA ensured a fully protonated and soluble cage.

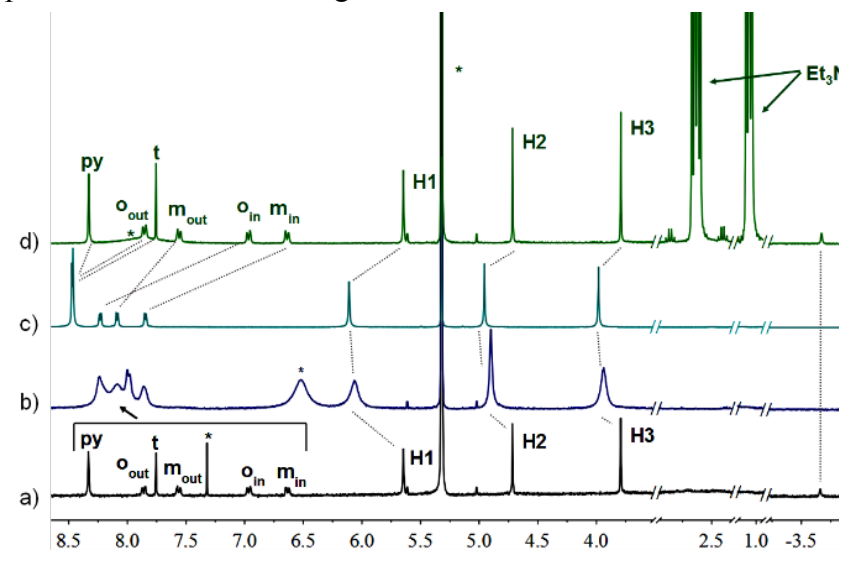

b)

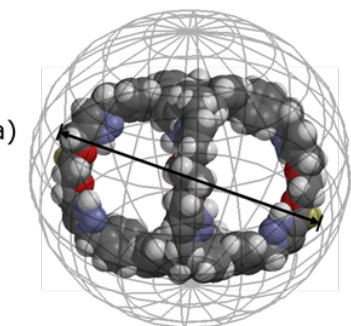

$\mathrm{d}(\mathrm{H} 2-\mathrm{H} 2) 27 \AA$

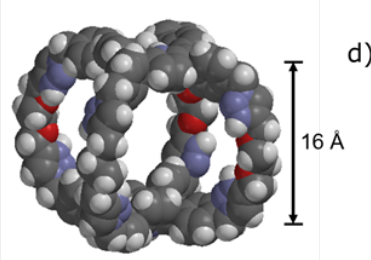

c)

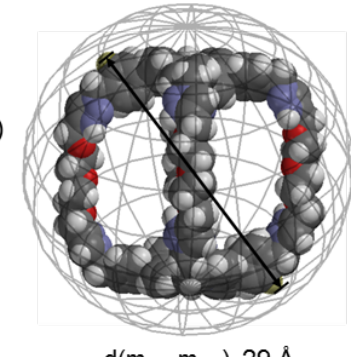

d)

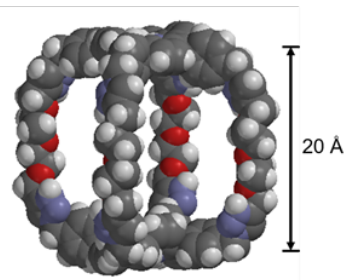

Figure 6. Energy-minimized structures (PM6, Spartan'16) of protonated cages 4 a), b) and 2 c), d). The hydrodynamic radii obtained from DOSY experiments of the spheres including $\mathbf{4}$ or $\mathbf{2}$ are $15.6 \AA$ (a) and $16.2 \AA$ (c) respectively. The mean plane distances between the porphyrins in the protonated cages $\mathbf{4}$ and $\mathbf{2}$ are indicated in $\mathrm{b}$ ) and d) respectively.

\section{CONCLUSION}

Figure 5. ${ }^{1} \mathrm{H}$ NMR spectra ( $300 \mathrm{MHz}, 298 \mathrm{~K}$ ) in $\mathrm{CD}_{2} \mathrm{Cl}_{2}$ of a) cage $\mathbf{4}, \mathrm{b})$ cage $\mathbf{4}$ after addition of 24 equiv TFA- $d$, c) cage $\mathbf{4}$ after addition of 1200 equiv TFA- $d$ and d) protonated cage 4 after neutralization with $\mathrm{Et}_{3} \mathrm{~N}$. *Residual solvents.

The DABCO-templated CuAAC reaction was effective to afford in $46 \%$ yield a bis-Zn(II)porphyrin cage 3•DABCO assembled with four flexible covalent linkers each incorporating two triazolyl ligands. Demetalation afforded quantitatively cage 4

The DOSY experiment confirmed an increased volume for the incorporating two free-base porphyrins. The compact conforprotonated cage $\mathbf{4}$ with a hydrodynamic radius of $15.6 \AA$ (SI mation that $\mathbf{3}$ adopts in solution expands by coordination of Figure S76), consistent with the repulsion of the numerous posi- DABCO to the Zn-porphyrins. The flexibility of the linkers as tively charged sites. The open form could be shrunk back to its well as the two types of constituents (porphyrin and triazole) flattened conformation by addition of a base (Figure 5d). The incorporated in cages $\mathbf{3}$ and $\mathbf{4}$ and in the related cages $\mathbf{1}$ and 2 same protonation reaction performed with cage $\mathbf{2}$ gave as ex- enables a chemically-induced breathing of the structure, based on pected based on the longer chemical linkers, a molecule of larger reversible complexation or protonation reaction. The distance size with a hydrodynamic radius of $16.2 \AA$ (SI Figure S84). De- between the porphyrins can thus be increased by silver(I) coordispites several attempts, no crystal suitable for X-ray diffraction nation to the peripheral triazoles and maximized by protonation analysis of cages in their expanded states, either by protonation or of the basic sites of cages 2 and 4 . These results demonstrated silver(I) coordination, could be obtained.

two ways of controlling large and reversible chemically-induced

Molecular models (PM6, Spartan '16) of the twelve-time protonated cages 4 (Figure 6a) and $\mathbf{2}$ (Figure $6 \mathrm{c}$ ) gave structures that fit well in spheres with hydrodynamic radii deduced from the DOSY experiments. From these models, the estimated mean plane distances between the porphyrins in the protonated cages 2 and 4 are substantial, respectively 20 and $16 \AA$ (Figure $6 \mathrm{~d}, \mathrm{~b}$ ). Whereas in cage 1 , the flattened porphyrins are separated by 3.81 $\AA$ in the compact conformation according to the X-ray structure, protonation fully expands the cage and increases this distance in solution to around $20 \AA$.

conformational changes in 3D structures that are particularly promising for the development of switchable receptors, sensors or reactors.

\section{EXPERIMENTAL SECTION}

General methods. All chemicals were of the best commercially available grade and used without further purification. $\mathrm{CH}_{2} \mathrm{Cl}_{2}$ and $\mathrm{CHCl}_{3}$ were distilled over $\mathrm{CaH}_{2}$ before use. THF was dried using dry-station GT S100 or distilled over sodium before use. Column chromatography was carried out using silica gel (Merck, silica gel 60, 63-200 or 40-63 $\mu \mathrm{m}$ ). Mass spectra were obtained by using a Bruker MicroTOF spectrometer in electrospray mode (ES-MS). Nuclear Magnetic Resonance (NMR) spectra for ${ }^{1} \mathrm{H},{ }^{13} \mathrm{C}$ were acquired on Bruker AVANCE 300, 400, 500 spectrometers. The ${ }^{1} \mathrm{H}$ and ${ }^{13} \mathrm{C}$ spectra were referenced to residual solvent peaks. $\left(\mathrm{CDCl}_{3}, 7.24\right.$ and $77.16 ; \mathrm{CD}_{2} \mathrm{Cl}_{2}, 5.32$ and 53.84; DMSO, 2.50 and 39.52; DMF, 8.03 and 163.15) Measures of self-diffusion coefficients were performed on a BRUKER 600 $\mathrm{MHz}$ spectrometer - Avance III, equipped with a DOTY (high strength $\mathrm{z}$ gradient probe DOTY Scientific, developing a pulse field gradient of $50 \mathrm{G} / \mathrm{cm} / \mathrm{A}$ ) or a BBI probe (Bruker BBI probe developing a pulse field gradient of $5 \mathrm{G} / \mathrm{cm} / \mathrm{A}$ ). The sample was 
thermostated at $298 \mathrm{~K}$. Diffusion NMR data were acquired using $\mathrm{CH}_{2} \mathrm{Cl}_{2}$ and the combined organic phases were dried over a Stimulated Echo pulse sequence with bipolar $\mathrm{z}$ gradients. Lim- $\mathrm{Na}_{2} \mathrm{SO}_{4}$, filtered and evaporated to dryness. The crude was puriited Eddy current Delay was fixed to $5 \mathrm{~ms}$. The diffusion time fied by column chromatography on silica gel $\left(\mathrm{CH}_{2} \mathrm{Cl} / 2 \mathrm{MeOH}\right.$ and the duration of the gradients were optimized for each sample. from 100/0 to 97/3) to afford 6 as a purple solid (258 $\mathrm{mg}, 80 \%$ A recycling delay of $3 \mathrm{~s}$ was respected between scans. DOSY yield). ${ }^{1} \mathbf{H}$ NMR $\left(300 \mathrm{MHz}, \mathrm{CDCl}_{3}+\right.$ pyridine- $\left.d_{5}\right): \delta(\mathrm{ppm}) 8.76$ spectra were generated by the DOSY module of the software $\left(8 \mathrm{H}, \mathrm{s}, \mathrm{H}_{\mathrm{py}}\right), 8.12\left(8 \mathrm{H}, \mathrm{d},{ }^{3} \mathrm{~J}=7.9 \mathrm{~Hz}, \mathrm{H}_{\mathrm{o}}\right), 7.77\left(4 \mathrm{H}, \mathrm{s}, \mathrm{H}_{\mathrm{t}}\right), 7.53$ NMRNotebook, using Inverse Laplace Transform (ILT) driven $\left(8 \mathrm{H}, \mathrm{d},{ }^{3} \mathrm{~J}=7.9 \mathrm{~Hz}, \mathrm{H}_{\mathrm{m}}\right), 5.79\left(8 \mathrm{H}, \mathrm{s}, \mathrm{H}_{1}\right), 4.74\left(8 \mathrm{H}, \mathrm{s}, \mathrm{H}_{2}\right), 4.17$ by maximum entropy, to build the diffusion dimension. The $\left(8 \mathrm{H}, \mathrm{d},{ }^{3} \mathrm{~J}=2.4 \mathrm{~Hz}, \mathrm{H}_{5}\right), 3.76-3.71\left(16 \mathrm{H}, \mathrm{m}, \mathrm{H}_{3-4}\right), 2.39\left(4 \mathrm{H}, \mathrm{t},{ }^{3} \mathrm{~J}\right.$ diffusion coefficients were corrected by using DMF as an inter- $\left.=2.4 \mathrm{~Hz}, \mathrm{H}_{\mathrm{Alkyne}}\right) ;{ }^{13} \mathbf{C}\left\{{ }^{1} \mathbf{H}\right\} \mathbf{N M R}\left(126 \mathrm{MHz}, \mathrm{CDCl}_{3}\right.$ pyridine- $\left.\mathrm{d}_{5}\right)$ : nal reference $\left(\eta=9.0410^{-4}\right.$ Pa.s and $D_{\text {ротҮ }}=1.4510^{-10} \mathrm{~m}^{2} . \mathrm{s}^{-1} ; \delta(\mathrm{ppm}) 149.9\left(\mathrm{C}_{2}\right), 145.7\left(\mathrm{C}_{10}\right), 143.9\left(\mathrm{C}_{4}\right), 135.1\left(\mathrm{C}_{5}\right), 133.7$ $\left.\mathrm{D}_{\mathrm{BBI}}=1.4110^{-10} \mathrm{~m}^{2} \cdot \mathrm{s}^{-1}\right)$. UV-visible spectra were recorded on a $\left(\mathrm{C}_{7}\right), 131.7\left(\mathrm{C}_{1}\right), 126.0\left(\mathrm{C}_{6}\right), 122.9\left(\mathrm{C}_{9}\right), 119.8\left(\mathrm{C}_{3}\right), 79.6\left(\mathrm{C}_{15}\right)$, Kontron Instruments UVIKON 860 spectrometer at $21^{\circ} \mathrm{C}$ with a $74.8\left(\mathrm{C}_{16}\right), 69.7\left(\mathrm{C}_{12}\right), 69.1\left(\mathrm{C}_{13}\right), 64.9\left(\mathrm{C}_{11}\right), 58.5\left(\mathrm{C}_{14}\right), 54.2\left(\mathrm{C}_{8}\right)$; $1 \mathrm{~cm}$ path cell.

HRMS (ESI) m/z: $[\mathrm{M}+\mathrm{H}]^{+}$calcd for $\mathrm{C}_{80} \mathrm{H}_{73} \mathrm{~N}_{16} \mathrm{O}_{8} \mathrm{Zn} 1449.5083$, Monoprotected dialkyne 7. A solution of lithium found $1449.5062(100) ; \mathrm{mp}>360^{\circ} \mathrm{C}$.

bis(trimethylsilyl)amide $(1 \mathrm{M}$ in THF, $11 \mathrm{mmol}, 11 \mathrm{~mL}, 1.5$ Synthesis of cage $3 \cdot \boldsymbol{D} \boldsymbol{A B C O}$. A solution of DABCO in equiv) was added to a stirred solution of $\alpha, \omega$-bis $\left(\mathrm{O}-\mathrm{CH}_{2} \mathrm{Cl}_{2}(1 \mathrm{~mL}, 141 \mu \mathrm{mol}, 16.0 \mathrm{mg}, 1\right.$ equiv $)$ was added to a propargyl)ethyleneglycol ${ }^{12}$ (7.29 mmol, $1 \mathrm{~g}, 1$ equiv) in dry THF stirred solution of 6 (141 $\mu$ mol, $206 \mathrm{mg}, 1$ equiv) and zinc $(600 \mathrm{~mL})$ at room temperature under argon. After $10 \mathrm{~min}$, TIP- [5,10,15,20-tetrakis(p-(azidomethyl)phenyl)porphyrin] 5 (141 $\mathrm{SCl}\left(6.77 \mathrm{mmol}, 1.45 \mathrm{~mL}, 0.9\right.$ equiv) was added to the reaction $\mu \mathrm{mol}, 127 \mathrm{mg}, 1$ equiv) in dry and degassed $\mathrm{CH}_{2} \mathrm{Cl}_{2}(140 \mathrm{~mL}, 1$ mixture. After $25 \mathrm{~min}$, aqueous $\mathrm{KOH}(1 \mathrm{M}, 200 \mathrm{~mL}$ ) was added. $\mathrm{mM})$. The reaction mixture, protected from light, was stirred at After removal of THF under reduced pressure, the aqueous layer room temperature under argon for 1 hour. $[\mathrm{Cu}(\operatorname{tren})] \mathrm{Br}(172$ was extracted with $\mathrm{CH}_{2} \mathrm{Cl}_{2}$. The organic phase was washed with $\mu \mathrm{mol}, 310 \mathrm{mg}, 1.2$ equiv) and $\mathrm{Na}_{2} \mathrm{CO}_{3}(670 \mu \mathrm{mol}, 70 \mathrm{mg}, 4.8$ water $(3 \times 100 \mathrm{~mL})$, dried over $\mathrm{Na}_{2} \mathrm{SO}_{4}$, filtered and evaporated to equiv) were added, and the reaction mixture was refluxed under dryness. The crude was purified by column chromatography on argon for 2 days. The mixture was cooled down to room temperasilica gel (petroleum ether/AcOEt 9:1) to afford 7 as a colorless ture, washed with water $(3 \times 150 \mathrm{~mL})$ and brine $(150 \mathrm{~mL})$, dried oil (724 mg, 36\% yield). ${ }^{1} \mathbf{H}$ NMR (400 MHz, $\left.\mathrm{CDCl}_{3}\right): \delta(\mathrm{ppm})$ over $\mathrm{Na}_{2} \mathrm{SO}_{4}$, filtered and evaporated to dryness. The crude prod$4.23\left(2 \mathrm{H}, \mathrm{s}, \mathrm{H}_{6}\right), 4.19\left(2 \mathrm{H}, \mathrm{d},{ }^{4} \mathrm{~J}=2.4 \mathrm{~Hz}, \mathrm{H}_{3}\right), 3.72\left(4 \mathrm{H}, \mathrm{m}, \mathrm{H}_{4-5}\right)$, uct was purified by column chromatography on alumina $2.41\left(1 \mathrm{H}, \mathrm{t},{ }^{4} \mathrm{~J}=2.4 \mathrm{~Hz}, \mathrm{H}_{1}\right), 1.05\left(21 \mathrm{H}, \mathrm{s}, \mathrm{H}_{\mathrm{TIPS}}\right) ;{ }^{\mathbf{1 3}} \mathbf{C}\{\mathbf{1 H}\} \mathrm{NMR}\left(\mathrm{CHCl}_{3} / \mathrm{MeOH} 98 / 2\right)$ to afford 3•DABCO as a purple solid. $\left(126 \mathrm{MHz}, \mathrm{CDCl}_{3}\right): \delta(\mathrm{ppm}) 103.1\left(\mathrm{C}_{7}\right) ; 88.0\left(\mathrm{C}_{8}\right) ; 79.7\left(\mathrm{C}_{2}\right) ;(159.6 \mathrm{mg}, 46 \%$ yield $){ }^{1} \mathbf{H} \mathbf{N M R}\left(500 \mathrm{MHz}, \mathrm{CDCl}_{3} / \mathrm{CD}_{3} \mathrm{OD} 9: 1\right)$ : $74.7\left(\mathrm{C}_{1}\right) ; 68.9\left(\mathrm{C}_{4}\right) ; 68.5\left(\mathrm{C}_{5}\right) ; 59.3\left(\mathrm{C}_{6}\right) ; 58.5\left(\mathrm{C}_{3}\right) ; 18.7\left(\mathrm{C}_{10}\right) ; \delta(\mathrm{ppm}) 8.33\left(16 \mathrm{H}, \mathrm{s}, \mathrm{H}_{\mathrm{py}}\right), 7.97\left(8 \mathrm{H}, \mathrm{s}, \mathrm{H}_{\mathrm{t}}\right), 7.77\left(8 \mathrm{H}, \mathrm{d},{ }^{3} \mathrm{~J}=\right.$ $11.3\left(\mathrm{C}_{9}\right)$; HRMS (ESI) m/z: $[\mathrm{M}+\mathrm{Na}]^{+}$calcd for $\left.\mathrm{C}_{17} \mathrm{H}_{30} \mathrm{NaO}_{2} \mathrm{Si} 7.6 \mathrm{~Hz}, \mathrm{H}_{\mathrm{o} \mathrm{out}}\right), 7.54\left(8 \mathrm{H}, \mathrm{d},{ }^{3} \mathrm{~J}=7.6 \mathrm{~Hz}, \mathrm{H}_{\mathrm{m} \text { out }}\right), 7.50\left(8 \mathrm{H}, \mathrm{d},{ }^{3} \mathrm{~J}=\right.$ 317.1907, found $317.1899(100) ; \quad[2 \mathrm{M}+\mathrm{Na}]^{+}$calcd for $7.6 \mathrm{~Hz}, \mathrm{H}_{\mathrm{o}}$ in $), 7.45\left(8 \mathrm{H}, \mathrm{d},{ }^{3} \mathrm{~J}=7.6 \mathrm{~Hz}, \mathrm{H}_{\mathrm{m} i n}\right), 5.76(16 \mathrm{H}, \mathrm{s}, \mathrm{H1})$, $\mathrm{C}_{34} \mathrm{H}_{60} \mathrm{NaO}_{4} \mathrm{Si}_{2} 611.3922$, found 611.3900 (16).

$4.70(16 \mathrm{H}, \mathrm{s}, \mathrm{H} 2), 3.78(16 \mathrm{H}, \mathrm{s}, \mathrm{H} 3),-5.07\left(12 \mathrm{H}, \mathrm{s}, \mathrm{H}_{\mathrm{DABCO}}\right)$;

TIPS-protected porphyrin 8. To a stirred solution of $7\left(1.80{ }^{1} \mathbf{H}\right.$ NMR $\left(400 \mathrm{MHz}, \mathrm{DMF}-d_{7}\right): \delta(\mathrm{ppm}) 8.50\left(16 \mathrm{H}, \mathrm{s}, \mathrm{H}_{\mathrm{t}}\right), 8.43$ mmol, $608 \mathrm{mg})$ and zinc (II) $\left[5,10,15,20\right.$-tetrakis $\left(\mathrm{p}-\left(8 \mathrm{H}, \mathrm{s}, \mathrm{H}_{\mathrm{py}}\right), 7.99\left(8 \mathrm{H}, \mathrm{d},{ }^{3} \mathrm{~J}=7.6 \mathrm{~Hz}, \mathrm{H}_{\mathrm{o} \text { out }}\right), 7.85\left(8 \mathrm{H}, \mathrm{d},{ }^{3} \mathrm{~J}=\right.\right.$ (azidomethyl)phenyl)porphyrin] $5\left(0.39 \mathrm{mmol}, 352 \mathrm{mg}, 1\right.$ equiv) $\left.7.6 \mathrm{~Hz}, \mathrm{H}_{\mathrm{m} \text { out }}\right), 7.73\left(8 \mathrm{H}, \mathrm{d},{ }^{3} \mathrm{~J}=7.6 \mathrm{~Hz}, \mathrm{H}_{\mathrm{o}}\right.$ in $), 7.56\left(8 \mathrm{H}, \mathrm{d},{ }^{3} \mathrm{~J}=\right.$ in anhydrous DMF $(39 \mathrm{~mL})$ were added $\mathrm{CuSO}_{4} \bullet 5 \mathrm{H}_{2} \mathrm{O}\left(0.397 .6 \mathrm{~Hz}, \mathrm{H}_{\mathrm{m}}\right.$ in $), 6.05(16 \mathrm{H}, \mathrm{s}, \mathrm{H} 1), 4.83(16 \mathrm{H}, \mathrm{s}, \mathrm{H} 2), 3.87(16 \mathrm{H}$, mmol, $98 \mathrm{mg}, 1$ equiv) and sodium ascorbate $(1.36 \mathrm{mmol}, 270 \mathrm{~s}, \mathrm{H} 3),-4.67\left(12 \mathrm{H}, \mathrm{s}, \mathrm{H}_{\mathrm{DABCO}}\right) ;{ }^{13} \mathbf{C}\left\{{ }^{1} \mathbf{H}\right\} \mathbf{N M R}(126 \mathrm{MHz}$, $\mathrm{mg}, 3.5$ equiv). The reaction mixture was degassed (3 vacuum- $\mathrm{CDCl}_{3} /$ methanol- $d_{4}$ 9:1): $\delta(\mathrm{ppm}) 149.5\left(\mathrm{C}_{2}\right), 145.7\left(\mathrm{C}_{12}\right), 143.1$ argon cycles) and stirred at $50^{\circ} \mathrm{C}$ overnight under argon. The $\left(\mathrm{C}_{4}\right), 134.8\left(\mathrm{C}_{5}\right), 134.8\left(\mathrm{C}_{7}\right), 133.9\left(\mathrm{C}_{9}\right), 131.4\left(\mathrm{C}_{1}\right), 126.7\left(\mathrm{C}_{6}\right)$, solvent was evaporated and the residue was dissolved in $\mathrm{CH}_{2} \mathrm{Cl}_{2}, 125.7\left(\mathrm{C}_{8}\right), 123.4\left(\mathrm{C}_{11}\right), 119.5\left(\mathrm{C}_{3}\right), 70.1\left(\mathrm{C}_{14}\right), 64.8\left(\mathrm{C}_{13}\right), 54.1$ The organic layer was washed with water $(3 \times 200 \mathrm{~mL})$, dried over $\left(\mathrm{C}_{10}\right), 38.4\left(\mathrm{C}_{\text {DABCO}}\right)$. HRMS (ESI) m/z: [M+3H] $]^{3+}$ calcd for $\mathrm{Na}_{2} \mathrm{SO}_{4}$, filtered and evaporated to dryness. The crude was puri- $\mathrm{C}_{134} \mathrm{H}_{119} \mathrm{~N}_{34} \mathrm{O}_{8} \mathrm{Zn}_{2} / 3$ 819.9506, found 819.9511 (95); UV-vis: fied by column chromatography on silica gel $\left(\mathrm{CH}_{2} \mathrm{Cl}_{2} / \mathrm{MeOH}\left(\mathrm{CHCl}_{3} / \mathrm{MeOH}(9: 1)\right) \lambda_{\max } \mathrm{nm}\left(\varepsilon \mathrm{M}^{-1} \mathrm{~cm}^{-1}\right) 424(985000) ; 560\right.$ from 100/0 to 90/10) to afford 8 as a purple solid (974 mg, 89\% (36 400); 601 (7 620); mp $>360^{\circ} \mathrm{C}$.

yield). ${ }^{1} \mathbf{H}$ NMR $\left(300 \mathrm{MHz}, \mathrm{CDCl}_{3}+\right.$ pyridine- $\left.\mathrm{d}_{5}\right): \delta(\mathrm{ppm}) 8.78$ Synthesis of cage 4 . Cage 4 was obtained starting from the re$\left(8 \mathrm{H}, \mathrm{s}, \mathrm{H}_{\mathrm{py}}\right), 8.15\left(8 \mathrm{H}, \mathrm{d},{ }^{3} \mathrm{~J}=7.9 \mathrm{~Hz}, \mathrm{H}_{\mathrm{o}}\right), 7.80\left(4 \mathrm{H}, \mathrm{s}, \mathrm{H}_{\mathrm{t}}\right), 7.57$ action mixture that afforded 3•DABCO. It was cooled to room $\left(8 \mathrm{H}, \mathrm{d},{ }^{3} \mathrm{~J}=7.9 \mathrm{~Hz}, \mathrm{H}_{\mathrm{m}}\right), 5.83\left(8 \mathrm{H}, \mathrm{s}, \mathrm{H}_{1}\right), 4.77\left(8 \mathrm{H}, \mathrm{s}, \mathrm{H}_{2}\right), 4.24$ temperature, washed with water $(3 \times 150 \mathrm{~mL})$ and $\mathrm{HCl} 37 \% \mathrm{w}(5$ $\left(8 \mathrm{H}, \mathrm{s}, \mathrm{H}_{5}\right), 3.75-3.79\left(16 \mathrm{H}, \mathrm{m}, \mathrm{H}_{3-4}\right), 1.01(84 \mathrm{H}, \mathrm{s}$, TIPS $\left.) ; \mathrm{mL}\right)$ was then added to demetalate quantitatively the porphyrins. ${ }^{13} \mathbf{C}\left\{{ }^{1} \mathbf{H}\right\}$ NMR $\left(126 \mathrm{MHz}, \mathrm{CDCl}_{3}+\right.$ pyridine- $\left.d_{5}\right): \delta(\mathrm{ppm}) 149.9$ The organic phase was then neutralized by adding $150 \mathrm{~mL}$ of an $\left(\mathrm{C}_{2}\right), 145.8\left(\mathrm{C}_{10}\right), 144.0\left(\mathrm{C}_{4}\right), 135.2\left(\mathrm{C}_{5}\right), 133.7\left(\mathrm{C}_{7}\right), 131.8\left(\mathrm{C}_{1}\right)$, aqueous saturated solution of $\mathrm{Na}_{2} \mathrm{CO}_{3}$, washed with distilled $126.0\left(\mathrm{C}_{6}\right), 123.0\left(\mathrm{C}_{9}\right), 119.8\left(\mathrm{C}_{3}\right), 103.2\left(\mathrm{C}_{15}\right), 87.9\left(\mathrm{C}_{16}\right), 69.8$ water $(3 \times 150 \mathrm{~mL})$, brine $(150 \mathrm{~mL})$, dried over $\mathrm{Na}_{2} \mathrm{SO}_{4}$ and $\left(\mathrm{C}_{12}\right), 68.7\left(\mathrm{C}_{13}\right), 64.9\left(\mathrm{C}_{11}\right), 59.3\left(\mathrm{C}_{14}\right), 54.2\left(\mathrm{C}_{8}\right), 18.7\left(\mathrm{C}_{18}\right), 11.2$ evaporated to dryness. The residue was purified by several col$\left(\mathrm{C}_{17}\right)$; HRMS (ESI) $\mathrm{m} / \mathrm{z}$ : $[\mathrm{M}]^{+}$calcd for $\mathrm{C}_{116} \mathrm{H}_{152} \mathrm{~N}_{16} \mathrm{O}_{8} \mathrm{Si}_{4} \mathrm{Zn}$ umn chromatographies on silica gel $\left(\mathrm{CH}_{2} \mathrm{Cl}_{2} / \mathrm{MeOH}(9: 1)\right)$ to 2073.0342, found 2075.0329 (100); UV-vis: $\left(\mathrm{CH}_{2} \mathrm{Cl}_{2}\right) \lambda_{\max } \mathrm{nm}\left(\varepsilon\right.$ afford cage 4 as a purple solid. (181 mg, 58\% yield) ${ }^{\mathbf{1}} \mathbf{H} \mathbf{~ N M R}$ $\left.\mathrm{M}^{-1} \mathrm{~cm}^{-1}\right) 423$ (395 000); 552 (4 360); 597 (16 300); mp > 360 ${ }^{\circ} \mathrm{C}$. (500 MHz, DMSO- $\left.d_{6}\right): \delta(\mathrm{ppm}) 8.38\left(16 \mathrm{H}, \mathrm{s}, \mathrm{H}_{\mathrm{py}}\right), 8.30(8 \mathrm{H}, \mathrm{s}$,

Alkyne functionalized porphyrin 6. TBAF• $3 \mathrm{H}_{2} \mathrm{O}\left(998 \mu \mathrm{mol}, \mathrm{H}_{\mathrm{t}}\right), 8.00\left(8 \mathrm{H}, \mathrm{d},{ }^{3} \mathrm{~J}=7.6 \mathrm{~Hz}, \mathrm{H}_{\mathrm{o} \text { out }}\right), 7.60\left(8 \mathrm{H}, \mathrm{d},{ }^{3} \mathrm{~J}=7.6 \mathrm{~Hz}, \mathrm{H}_{\mathrm{m}}\right.$ $315 \mathrm{mg}, 4.5$ equiv) was added to a stirred solution of $8\left(224^{\text {out }}\right), 6.81\left(8 \mathrm{H}, \mathrm{d},{ }^{3} \mathrm{~J}=7.6 \mathrm{~Hz}, \mathrm{H}_{\mathrm{o}}\right.$ in $), 6.11\left(8 \mathrm{H}, \mathrm{d},{ }^{3} \mathrm{~J}=7.6 \mathrm{~Hz}, \mathrm{H}_{\mathrm{m}}\right.$ umol, $466 \mathrm{mg}, 1$ equiv) in THF $(50 \mathrm{~mL})$. The reaction mixture in $), 5.56(16 \mathrm{H}, \mathrm{s}, \mathrm{H} 1), 4.58(16 \mathrm{H}, \mathrm{s}, \mathrm{H} 2), 3.66(16 \mathrm{H}, \mathrm{s}, \mathrm{H} 3),-$ protected from light was stirred overnight at room temperature. $3.19(4 \mathrm{H}, \mathrm{s}, \mathrm{NH}){ }^{1} \mathbf{H}$ NMR $\left(500 \mathrm{MHz}, \mathrm{DMF}-d_{7}\right): \delta(\mathrm{ppm}) 8.45$ After removal of the solvent under reduced pressure, the residue $\left(16 \mathrm{H}, \mathrm{s}, \mathrm{H}_{\mathrm{py}}\right), 8.39\left(8 \mathrm{H}, \mathrm{s}, \mathrm{H}_{\mathrm{t}}\right), 8.02\left(8 \mathrm{H}, \mathrm{d},{ }^{3} \mathrm{~J}=7.6 \mathrm{~Hz}, \mathrm{H}_{\mathrm{o}}\right.$ out $)$, was dissolved in $\mathrm{CH}_{2} \mathrm{Cl}_{2}$. The organic layer was washed with $7.78\left(8 \mathrm{H}, \mathrm{d},{ }^{3} \mathrm{~J}=7.6 \mathrm{~Hz}, \mathrm{H}_{\mathrm{m} \text { out }}\right), 7.04\left(8 \mathrm{H}, \mathrm{d},{ }^{3} \mathrm{~J}=7.6 \mathrm{~Hz}, \mathrm{H}_{\mathrm{o}}\right.$ in), water, the aqueous phase was extracted several times with $6.82\left(8 \mathrm{H}, \mathrm{d},{ }^{3} \mathrm{~J}=7.6 \mathrm{~Hz}, \mathrm{H}_{\mathrm{min}}\right), 5.88(16 \mathrm{H}, \mathrm{s}, \mathrm{H1}), 4.70(16 \mathrm{H}, \mathrm{s}$, $\mathrm{H} 2), 3.76(16 \mathrm{H}, \mathrm{s}, \mathrm{H} 3),-3.31(4 \mathrm{H}, \mathrm{s}, \mathrm{NH}) .{ }^{1} \mathbf{H}$ NMR $(300 \mathrm{MHz}$, 
$\left.\mathrm{CD}_{2} \mathrm{Cl}_{2}\right): \delta(\mathrm{ppm}) 8.33\left(16 \mathrm{H}, \mathrm{s}, \mathrm{H}_{\mathrm{py}}\right), 7.86\left(8 \mathrm{H}, \mathrm{d},{ }^{3} \mathrm{~J}=7.6 \mathrm{~Hz},\left(8 \mathrm{H}, \mathrm{s}, \mathrm{H}_{\mathrm{t}}\right), 7.76\left(32 \mathrm{H}, \mathrm{m}, \mathrm{H}_{\mathrm{o}} \mathrm{BArF}\right), 7.72\left(8 \mathrm{H}, \mathrm{d},{ }^{3} \mathrm{~J}=7.6 \mathrm{~Hz}\right.\right.$, $\left.\mathrm{H}_{\mathrm{o} \mathrm{out}}\right), 7.76\left(8 \mathrm{H}, \mathrm{s}, \mathrm{H}_{\mathrm{t}}\right), 7.56\left(8 \mathrm{H}, \mathrm{d},{ }^{3} \mathrm{~J}=7.6 \mathrm{~Hz}, \mathrm{H}_{\mathrm{m} \text { out }}\right), 6.96\left(8 \mathrm{H}_{\mathrm{m} \mathrm{out}}\right), 7.62\left(8 \mathrm{H}, \mathrm{d},{ }^{3} \mathrm{~J}=7.6 \mathrm{~Hz}, \mathrm{H}_{\mathrm{o} \mathrm{in}}\right), 7.58\left(16 \mathrm{H}, \mathrm{m}, \mathrm{H}_{\mathrm{p}} \mathrm{BArF}\right)$, $\left.\mathrm{H}, \mathrm{d},{ }^{3} \mathrm{~J}=7.6 \mathrm{~Hz}, \mathrm{H}_{\mathrm{o} \text { in }}\right), 6.63\left(8 \mathrm{H}, \mathrm{d},{ }^{3} \mathrm{~J}=7.6 \mathrm{~Hz}, \mathrm{H}_{\mathrm{m} \mathrm{in}}\right), 5.65\left(167.41\left(8 \mathrm{H}, \mathrm{d},{ }^{3} \mathrm{~J}=7.6 \mathrm{~Hz}, \mathrm{H}_{\mathrm{m} \text { in }}\right), 5.85(16 \mathrm{H}, \mathrm{s}, \mathrm{H1}), 4.73(16 \mathrm{H}, \mathrm{s}\right.$, $\mathrm{H}, \mathrm{s}, \mathrm{H} 1), 4.72(16 \mathrm{H}, \mathrm{s}, \mathrm{H} 2), 3.79(16 \mathrm{H}, \mathrm{s}, \mathrm{H} 3),-3.66(4 \mathrm{H}, \mathrm{s}, \mathrm{H} 2), 3.83(16 \mathrm{H}, \mathrm{s}, \mathrm{H} 3) .{ }^{1} \mathbf{H}$ NMR $\left(500 \mathrm{MHz}, \mathrm{DMF}-d_{7}\right): \delta(\mathrm{ppm})$ $\mathrm{NH}) ;{ }^{13} \mathbf{C}\left\{\left\{^{1} \mathbf{H}\right\}\right.$ NMR $\left(126 \mathrm{MHz}, \mathrm{DMSO}-d_{6}\right): \delta(\mathrm{ppm}) 144.4\left(\mathrm{C}_{12}\right), 8.83\left(8 \mathrm{H}, \mathrm{s}, \mathrm{H}_{\mathrm{t}}\right), 8.54\left(16 \mathrm{H}, \mathrm{s}, \mathrm{H}_{\mathrm{py}}\right), 8.16\left(8 \mathrm{H}, \mathrm{d},{ }^{3} \mathrm{~J}=7.6 \mathrm{~Hz}, \mathrm{H}_{\mathrm{o}}\right.$ $140.3\left(\mathrm{C}_{4}\right), 135.4\left(\mathrm{C}_{9}\right), 133.9\left(\mathrm{C}_{5+7}\right), 131.1\left(\mathrm{C}_{1}\right), 126.0\left(\mathrm{C}_{6}\right), 124.8$ out $), 7.97\left(8 \mathrm{H}, \mathrm{d},{ }^{3} \mathrm{~J}=7.6 \mathrm{~Hz}, \mathrm{H}_{\mathrm{m} \text { out }}\right), 7.81(48 \mathrm{H}, \mathrm{m}, \mathrm{BArF}), 7.78$ $\left(\mathrm{C}_{8}\right), 124.6\left(\mathrm{C}_{11}\right), 119.2\left(\mathrm{C}_{3}\right), 69.0\left(\mathrm{C}_{14}\right), 63.6\left(\mathrm{C}_{13}\right), 52.2\left(\mathrm{C}_{10}\right) ;\left(8 \mathrm{H}, \mathrm{d},{ }^{3} \mathrm{~J}=7.6 \mathrm{~Hz}, \mathrm{H}_{\mathrm{o}}\right.$ in $), 7.44\left(\mathrm{~d},{ }^{3} \mathrm{~J}=7.6 \mathrm{~Hz}, 8 \mathrm{H}, \mathrm{H}_{\mathrm{m}}\right.$ in $), 6.21$ pyrrolic ${ }^{13} \mathrm{C} \mathrm{C}_{2}$ are too enlarged to be observed at 298K; HRMS (s, $\left.16 \mathrm{H}, \mathrm{H} 1\right), 4.97(\mathrm{~s}, 16 \mathrm{H}, \mathrm{H} 2), 4.01(\mathrm{~s}, 16 \mathrm{H}, \mathrm{H} 3) ;{ }^{13} \mathbf{C}\left\{{ }^{1} \mathbf{H}\right\}$ (ESI) $\mathrm{m} / \mathrm{z}:[\mathrm{M}+2 \mathrm{H}]^{2+}$ calcd for $\mathrm{C}_{128} \mathrm{H}_{110} \mathrm{~N}_{32} \mathrm{O}_{8} / 21111.4587$, found NMR $\left(126 \mathrm{MHz}, \mathrm{CD}_{2} \mathrm{Cl}_{2}\right): \delta(\mathrm{ppm}) 162.1\left(\mathrm{q},{ }^{1} \mathrm{~J}_{\mathrm{B}-\mathrm{C}}=50 \mathrm{~Hz}\right.$, 1111.4560 (100); $[\mathrm{M}+\mathrm{H}]^{+}$calcd for $\left.\mathrm{C}_{128} \mathrm{H}_{109} \mathrm{~N}_{32} \mathrm{O}_{8} 2221.9101, \mathrm{BArF}\right), 150.1\left(\mathrm{C}_{2}\right), 145.9\left(\mathrm{C}_{12}\right), 143.6\left(\mathrm{C}_{4}\right), 135.9\left(\mathrm{C}_{7}\right), 135.2(\mathrm{~s}$, found 2222.9086; UV-vis: (dmso) $\lambda_{\max } \mathrm{nm}\left(\varepsilon \mathrm{M}^{-1} \mathrm{~cm}^{-1}\right) 417(780 \mathrm{BArF}), 134.5\left(\mathrm{C}_{5}\right), 133.4\left(\mathrm{C}_{9}\right), 131.9\left(\mathrm{C}_{1}\right), 129.2\left(\mathrm{q},{ }^{2} \mathrm{~J}_{\mathrm{C}-\mathrm{F}}=31.5\right.$ 000); 516 (34 600); 552 (16 300); 590 (10 200); 646 (8 880); Hz, BArF), $126.5\left(\mathrm{C}_{6}\right), 125.8\left(\mathrm{C}_{8}\right), 124.9\left(\mathrm{q},{ }^{1} \mathrm{~J}_{\mathrm{C}-\mathrm{F}}=272 \mathrm{~Hz}\right.$ $\mathrm{mp}>360^{\circ} \mathrm{C}$.

BArF $), 122.8\left(\mathrm{C}_{11}\right), 120.2\left(\mathrm{C}_{3}\right), 117.9(\mathrm{~s}, \mathrm{BArF}), 70.6\left(\mathrm{C}_{14}\right), 63.6$

Synthesis of cage 3. $\mathrm{Zn}(\mathrm{OAc})_{2} \cdot 2 \mathrm{H}_{2} \mathrm{O}\left(49.5 \mu \mathrm{mol}, 11 \mathrm{mg}, 2.2\left(\mathrm{C}_{13}\right), 55.6\left(\mathrm{C}_{10}\right) ;{ }^{19} \mathbf{F}\left\{{ }^{1} \mathbf{H}\right\} \mathbf{N M R}\left(282 \mathrm{MHz}, \mathrm{CD}_{2} \mathrm{Cl}_{2}\right): \delta(\mathrm{ppm})-\right.$ equiv) were added to a stirred solution of cage $4\left(22.5 \mu \mathrm{mol}, 5063.89 ;{ }^{11} \mathbf{B} \mathbf{N M R}\left(96 \mathrm{MHz}, \mathrm{CD}_{2} \mathrm{Cl}_{2}\right): \delta(\mathrm{ppm})-6.59 ; \mathbf{H R M S}\right.$ $\mathrm{mg}, 1$ equiv) in $20 \mathrm{~mL}$ of $\mathrm{CHCl}_{3} / \mathrm{MeOH}(9: 1)$. After $2 \mathrm{~h}$ at $60^{\circ} \mathrm{C}$, (ESI) m/z: [M-4BArF] ${ }^{4+}$ calcd for $\mathrm{C}_{128} \mathrm{H}_{104} \mathrm{Ag}_{4} \mathrm{~N}_{32} \mathrm{O}_{8} \mathrm{Zn}_{2} / 4$ the solvents were removed under reduced pressure. The residue 693.0870, found 693.0881 (100); [M-4BArF-Ag] ${ }^{3+}$ calcd for was then washed with $\mathrm{MeOH}$ to remove the unreacted $\mathrm{C}_{128} \mathrm{H}_{104} \mathrm{Ag}_{3} \mathrm{~N}_{32} \mathrm{O}_{8} \mathrm{Zn}_{2} / 3$ 888.4811, found 888.4842 (41); [M$\mathrm{Zn}(\mathrm{OAc})_{2} \cdot 2 \mathrm{H}_{2} \mathrm{O}$ and dried under vacuum to afford cage 3 as a $\left.3 \mathrm{BArF}\right]^{3+}$ calcd for $\mathrm{C}_{128} \mathrm{H}_{104} \mathrm{Ag}_{4} \mathrm{BF}_{24} \mathrm{~N}_{32} \mathrm{O}_{8} \mathrm{Zn}_{2} / 3 \quad 1211.8045$, purple solid (52.8 mg, $22.5 \mu \mathrm{mol}, 100 \%)$. ${ }^{1} \mathbf{H}$ NMR (500 MHz, Found $1211.8067(10) ; \mathrm{mp}>360^{\circ} \mathrm{C}$.

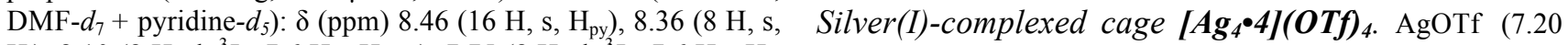
$\left.\mathrm{H}_{\mathrm{t}}\right), 8.10\left(8 \mathrm{H}, \mathrm{d},{ }^{3} \mathrm{~J}=7.6 \mathrm{~Hz}, \mathrm{H}_{\mathrm{o} \text { out }}\right), 7.75\left(8 \mathrm{H}, \mathrm{d},{ }^{3} \mathrm{~J}=7.6 \mathrm{~Hz}, \mathrm{H}_{\mathrm{m}} \mu \mathrm{mol}, 1.85 \mathrm{mg}, 4\right.$ equiv $)$ was added at room temperature to a out), $7.23\left(8 \mathrm{H}, \mathrm{d}, \mathrm{H}_{\mathrm{o}}\right.$ in $), 6.77\left(8 \mathrm{H}, \mathrm{br} \mathrm{s}, \mathrm{H}_{\mathrm{m} \text { in }}\right), 5.83(16 \mathrm{H}, \mathrm{s}, \mathrm{H} 1)$, stirred solution of cage $4(1.80 \mu \mathrm{mol}, 4.00 \mathrm{mg}, 1 \mathrm{equiv})$ in dis$4.71(16 \mathrm{H}, \mathrm{s}, \mathrm{H} 2), 3.77(16 \mathrm{H}, \mathrm{s}, \mathrm{H} 3) ;{ }^{1} \mathbf{H}$ NMR $\left(500 \mathrm{MHz}\right.$, tilled $\mathrm{CHCl}_{3} / \mathrm{CH}_{2} \mathrm{Cl}_{2} / \mathrm{MeOH}(5: 5: 1,11 \mathrm{~mL})$, protected from light. DMSO- $\left.d_{6}\right): \delta(\mathrm{ppm}) 8.37\left(16 \mathrm{H}, \mathrm{s}, \mathrm{H}_{\mathrm{py}}\right), 8.29\left(8 \mathrm{H}, \mathrm{s}, \mathrm{H}_{\mathrm{t}}\right), 8.01(8 \mathrm{~A}$ purple precipitate formed immediately. After 20 minutes, the $\left.\mathrm{H}, \mathrm{d},{ }^{3} \mathrm{~J}=7.6 \mathrm{~Hz}, \mathrm{H}_{\mathrm{o} \mathrm{out}}\right), 7.59\left(8 \mathrm{H}, \mathrm{d},{ }^{3} \mathrm{~J}=7.6 \mathrm{~Hz}, \mathrm{H}_{\mathrm{m} \text { out }}\right), 6.97$ ( 8 solvent was removed and the residue was dried under vacuum to $\left.\mathrm{H}, \mathrm{d},{ }^{3} \mathrm{~J}=7.6 \mathrm{~Hz}, \mathrm{H}_{\mathrm{o} \text { in }}\right), 6.26\left(8 \mathrm{H}, \mathrm{d},{ }^{3} \mathrm{~J}=7.6 \mathrm{~Hz}, \mathrm{H}_{\mathrm{m}}\right.$ in $), 5.61$ (16 afford a purple solid $\left(5.9 \mathrm{mg}\right.$, quantitative yield). ${ }^{1} \mathbf{H}$ NMR $(500$ H, s, H1), $4.60(16 \mathrm{H}, \mathrm{s}, \mathrm{H} 2), 3.68(16 \mathrm{H}, \mathrm{s}, \mathrm{H} 3) ;{ }^{13} \mathbf{C}\left\{{ }^{1} \mathbf{H}\right\}$ NMR MHz, DMF- $\left.d_{7}\right): \delta(\mathrm{ppm}) 8.82\left(8 \mathrm{H}, \mathrm{s}, \mathrm{H}_{\mathrm{t}}\right), 8.59\left(16 \mathrm{H}, \mathrm{s}, \mathrm{H}_{\mathrm{py}}\right)$, $\left(126 \mathrm{MHz}, \mathrm{DMF}-d_{7}+\right.$ pyridine- $\left.d_{5}\right): \delta(\mathrm{ppm}) 150.6\left(\mathrm{C}_{2}\right), 146.28 .25\left(8 \mathrm{H}, \mathrm{d},{ }^{3} \mathrm{~J}=7.6 \mathrm{~Hz}, \mathrm{H}_{\mathrm{o}}\right.$ out $)$, vers $8.05\left(8 \mathrm{H}, \mathrm{d},{ }^{3} \mathrm{~J}=7.6 \mathrm{~Hz}\right.$, $\left.\left(\mathrm{C}_{12}\right), 143.7\left(\mathrm{C}_{4}\right), 136.4\left(\mathrm{C}_{9}\right), 135.8\left(\mathrm{C}_{7}\right), 135.5\left(\mathrm{C}_{5}\right), 132.4\left(\mathrm{C}_{1}\right), \mathrm{H}_{\mathrm{m} \text { out }}\right), 7.81\left(8 \mathrm{H}, \mathrm{d},{ }^{3} \mathrm{~J}=7.6 \mathrm{~Hz}, \mathrm{H}_{\mathrm{o}}\right.$ in $), 7.46\left(8 \mathrm{H}, \mathrm{d},{ }^{3} \mathrm{~J}=7.6 \mathrm{~Hz}\right.$, $127.2\left(\mathrm{C}_{6}\right), 126.4\left(\mathrm{C}_{8}\right), 125.4\left(\mathrm{C}_{11}\right), 120.9\left(\mathrm{C}_{3}\right), 70.7\left(\mathrm{C}_{14}\right), 65.4 \mathrm{H}_{\mathrm{m}}$ in $), 6.23(16 \mathrm{H}, \mathrm{s}, \mathrm{H} 1), 4.96(\mathrm{~s}, 16 \mathrm{H}, \mathrm{H} 2), 4.00(16 \mathrm{H}, \mathrm{m}, \mathrm{H} 3),-$ $\left(\mathrm{C}_{13}\right), \quad 54.0\left(\mathrm{C}_{10}\right)$; HRMS (ESI) $\mathrm{m} / \mathrm{z}:[\mathrm{M}+2 \mathrm{H}]{ }^{2+}$ calcd for $3.45(4 \mathrm{H}, \mathrm{s}, \mathrm{NH}) ;{ }^{13} \mathbf{C}\left\{{ }^{1} \mathbf{H}\right\} \mathbf{N M R}\left(126 \mathrm{MHz}, \mathrm{DMF}-d_{7}\right): \delta(\mathrm{ppm})$ $\mathrm{C}_{128} \mathrm{H}_{106} \mathrm{~N}_{32} \mathrm{O}_{8} \mathrm{Zn}_{2} / 2$ 1173.3722, found 1173.3729 (100); UV-vis: $146.8\left(\mathrm{C}_{12}\right), 142.5\left(\mathrm{C}_{4}\right), 136.7\left(\mathrm{C}_{9}\right), 136.3\left(\mathrm{C}_{7}\right), 135.6\left(\mathrm{C}_{5}\right), 131.9$ (dmso) $\lambda_{\max } \mathrm{nm}\left(\varepsilon \mathrm{M}^{-1} \mathrm{~cm}^{-1}\right) 424(1100000) ; 560$ (41 100); $601\left(\mathrm{br}, \mathrm{C}_{1}\right), 127.9\left(\mathrm{C}_{6}\right), 126.8\left(\mathrm{C}_{8}\right), 125.6\left(\mathrm{C}_{11}\right), 122.6\left(\mathrm{q},{ }^{1} \mathrm{~J}_{\mathrm{C}-\mathrm{F}}=322\right.$ (19 700) $\left.\left.\left(\mathrm{CHCl}_{3} / \mathrm{MeOH}(9: 1)\right) \lambda_{\max } \mathrm{nm} 420 ; 558 ; 594\right) ; \mathrm{mp}>\mathrm{Hz}, \mathrm{OTf}\right), 120.6\left(\mathrm{C}_{3}\right), 70.7\left(\mathrm{C}_{14}\right), 64.2\left(\mathrm{C}_{13}\right), 54.8\left(\mathrm{C}_{10}\right) ;{ }^{19} \mathbf{F}\left\{{ }^{1} \mathbf{H}\right\}$ $360^{\circ} \mathrm{C}$.

NMR $\left(282 \mathrm{MHz}, \mathrm{DMF}-d_{7}\right): \delta(\mathrm{ppm})-79.64 ;$ HRMS (ESI) $\mathrm{m} / \mathrm{z}$ :

Silver(I)-complexed cage $\left[\mathbf{A g}_{4} \cdot 3 /(\boldsymbol{O T f})_{4}\right.$. AgOTf $\left(25.5 \mu \mathrm{mol}\right.$, [M-4OTf] ${ }^{4+}$ calcd for $\mathrm{C}_{128} \mathrm{H}_{108} \mathrm{Ag}_{4} \mathrm{~N}_{32} \mathrm{O}_{8} / 4$ 662.1302, found $6.56 \mathrm{mg}, 4$ equiv) was added at room temperature to a stirred 662.1311 (100); [M-4OTf-Ag] $]^{3+}$ calcd for $\mathrm{C}_{128} \mathrm{H}_{108} \mathrm{Ag}_{3} \mathrm{~N}_{32} \mathrm{O}_{8} / 3$ solution of cage $3\left(6.39 \mu \mathrm{mol}, 15.0 \mathrm{mg}, 1\right.$ equiv) in distilled 847.2055 , found $847.2085(55) ; \mathrm{mp}>360^{\circ} \mathrm{C}$.

$\mathrm{CHCl}_{3} / \mathrm{CH}_{2} \mathrm{Cl}_{2} / \mathrm{MeOH}(5: 5: 1,25 \mathrm{~mL})$, protected from light. A Recovering cage 3 from $\left[\boldsymbol{A g} \boldsymbol{g}_{4} \cdot 3 \boldsymbol{J}(\boldsymbol{O T f})_{4}\right.$. An excess of purple precipitate formed immediately. The solvent was removed $\mathrm{LiCl}(16 \mu \mathrm{mol}, 0.7 \mathrm{mg}, 10$ equiv) was added at room temperature and the residue was dried under vacuum to afford a purple solid to a stirred solution of cage $\left[\mathbf{A g}_{4} \bullet \mathbf{3}\right](\mathbf{O T f})_{4}(1.6 \mu \mathrm{mol}, 5.5 \mathrm{mg}, 1$ (21.6 mg, quantitative yield). ${ }^{1} \mathbf{H}$ NMR $\left(500 \mathrm{MHz}, \mathrm{DMF}-d_{7}\right): \delta$ equiv) in DMF- $d_{7}$. A white precipitate formed immediately. After (ppm) $8.83\left(8 \mathrm{H}, \mathrm{s}, \mathrm{H}_{\mathrm{t}}\right), 8.51\left(16 \mathrm{H}, \mathrm{s}, \mathrm{H}_{\mathrm{py}}\right), 8.11\left(8 \mathrm{H}, \mathrm{d},{ }^{3} \mathrm{~J}=7.6\right.$ filtration, the solvent was removed and the residue was washed $\left.\mathrm{Hz}, \mathrm{H}_{\mathrm{o} \text { out }}\right), 7.95\left(8 \mathrm{H}, \mathrm{d},{ }^{3} \mathrm{~J}=7.6 \mathrm{~Hz}, \mathrm{H}_{\mathrm{m} \text { out }}\right), 7.81\left(8 \mathrm{H}, \mathrm{d},{ }^{3} \mathrm{~J}=7.6\right.$ with methanol and centrifugated. The residue was dried under $\mathrm{Hz}, \mathrm{H}_{\mathrm{o}}$ in $), 7.44\left(8 \mathrm{H}, \mathrm{d},{ }^{3} \mathrm{~J}=7.6 \mathrm{~Hz}, \mathrm{H}_{\mathrm{m}}\right.$ in), 6.21 (s, $\left.16 \mathrm{H}, \mathrm{H1}\right)$, vacuum to afford a purple solid (3.5 mg, 90\% yield).

$4.97(\mathrm{~s}, 16 \mathrm{H}, \mathrm{H} 2), 4.01(\mathrm{~s}, 16 \mathrm{H}, \mathrm{H} 3) ;{ }^{13} \mathbf{C}\left\{{ }^{1} \mathbf{H}\right\} \mathbf{N M R}(126 \mathrm{MHz}$, DMF- $\left.d_{7}\right): \delta(\mathrm{ppm}) 150.5\left(\mathrm{C}_{2}\right), 146.9\left(\mathrm{C}_{12}\right), 144.0\left(\mathrm{C}_{4}\right), 136.2\left(\mathrm{C}_{7}\right)$, $136.0\left(\mathrm{C}_{9}\right), 135.8\left(\mathrm{C}_{5}\right), 132.3\left(\mathrm{C}_{1}\right), 127.5\left(\mathrm{C}_{6}\right), 126.4\left(\mathrm{C}_{8}\right), 125.6$ $\left(\mathrm{C}_{11}\right), 122.6\left(\mathrm{q},{ }^{1} \mathrm{~J}_{\mathrm{C}-\mathrm{F}}=320 \mathrm{~Hz}, \mathrm{OTf}\right), 120.8\left(\mathrm{C}_{3}\right), 70.7\left(\mathrm{C}_{14}\right), 63.9$ $\left(\mathrm{C}_{13}\right), 55.1\left(\mathrm{C}_{10}\right) ;{ }^{19} \mathbf{F}\left\{{ }^{1} \mathbf{H}\right\} \mathbf{N M R}\left(282 \mathrm{MHz}, \mathrm{DMF}-d_{7}\right): \delta(\mathrm{ppm})-$ ASSOCIATED CONTENT

79.63; HRMS (cryospray ESI) $\mathrm{m} / \mathrm{z}$ : $[\mathrm{M}-4 \mathrm{OTf}]^{4+}$ calcd for Supporting Information.

$\mathrm{C}_{128} \mathrm{H}_{104} \mathrm{Ag}_{4} \mathrm{~N}_{32} \mathrm{O}_{8} \mathrm{Zn}_{2} / 4693.086992$, found 693.085448 (10); [M- ${ }^{1} \mathrm{H},{ }^{13} \mathrm{C}, 2 \mathrm{D}$ NMR spectra and HRMS of new compounds and crys4OTf-Ag] ${ }^{3+}$ calcd for $\mathrm{C}_{128} \mathrm{H}_{104} \mathrm{Ag}_{3} \mathrm{~N}_{32} \mathrm{O}_{8} \mathrm{Zn}_{2} / 3$ 888.481139, found tallographic data for 1•DABCO (CCDC 1535914) and 3•DABCO $888.479004(100) ; \mathrm{mp}>360^{\circ} \mathrm{C}$. (CCDC 1535953) (PDF).

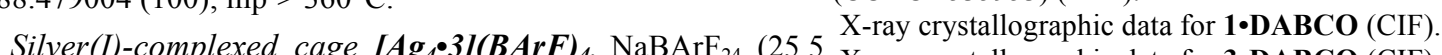

Silver(I)-complexed cage $\boldsymbol{I A g}_{4} \cdot \mathbf{3} \boldsymbol{J}(\boldsymbol{B} \boldsymbol{A r F})_{4} \cdot \mathrm{NaBArF}_{24}(25.5 \mathrm{X}$-ray crystallographic data for $\mathbf{3} \cdot \mathbf{D A B C O}$ (CIF).

$\mu \mathrm{mol}, 22.6 \mathrm{mg}$, 4 equiv) was added to a stirred solution of cage This material is available free of charge via the Internet at $\left[\mathbf{A g}_{4} \bullet \mathbf{3}\right](\mathbf{O T f})_{4}\left(6.39 \mu \mathrm{mol}, 21.6 \mathrm{mg}, 1\right.$ equiv) in $\mathrm{CH}_{2} \mathrm{Cl}_{2}$. After 1 http://pubs.acs.org.

hour, the compound was completely soluble. The reaction mixture was then washed with water $(3 \times 20 \mathrm{~mL})$, dried over $\mathrm{Na}_{2} \mathrm{SO}_{4}$ AUTHOR INFORMATION and the solvent was removed under vacuum to obtain a purple solid $\left(39.0 \mathrm{mg}, 98 \%\right.$ yield). ${ }^{1} \mathbf{H}$ NMR $\left(500 \mathrm{MHz}, \mathrm{CD}_{2} \mathrm{Cl}_{2}\right): \delta$ Corresponding Authors (ppm) $8.61\left(16 \mathrm{H}, \mathrm{s}, \mathrm{H}_{\mathrm{py}}\right), 8.21\left(8 \mathrm{H}, \mathrm{d},{ }^{3} \mathrm{~J}=7.6 \mathrm{~Hz}, \mathrm{H}_{\mathrm{o} \text { out }}\right), 7.88 *$ E-mail: sdurot@unistra.fr 


\section{ACKNOWLEDGMENT}

Chem. Soc. 2014, 136, 15126; (b) Zhang, J.; Zheng, X.; Jiang, R.; Yu, Y.; Li, Y.; Liu, H.; Li, Q.; Shuai, Z.; Li, Y. RSC Adv. 2014, 4, The International Center for Frontier Research in Chemistry, icFRC 27389; (c) Taesch, J.; Heitz, V.; Topic, F.; Rissanen, K. Chem. (www.icfrc.fr) and the LaBex-CSC are gratefully acknowledged for Commun. 2012, 48, 5118; (d) Ding, H.; Wu, X.; Zeller, M.; Xie, Y.; $\mathrm{PhD}$ fellowships to LK and LS and for financial support. We also Wang, C. J. Org. Chem. 2015, 80, 9360; (e) Hajjaj, F.; Tashiro, K.; thank the ANR Agency for the financial support of the project ANR Nikawa, H.; Mizorogi, N.; Akasaka, T.; Nagase, S.; Furukawa, K.; 14-CE06-0010 "Switchables cages", We are grateful to Dr Lydia Kato, T.; Aida, T. J. Am. Chem. Soc. 2011, 133, 9290; (f) Rogers, L.; Karmazin (Crystallographic Service, Faculté de Chimie de Burke-Murphy, E.; Senge, M. O. Eur. J. Org. Chem. 2014, 2014, l'Université Strasbourg) and to Dr Eduardo C. Escudero-Adan (X-4283; (g) Ding, H.; Meng, X.; Cui, X.; Yang, Y.; Zhou, T.; Wang, ray diffraction, ICIQ, Tarragona) for the structure determinations. C.; Zeller, M.; Wang, C. Chem. Commun. 2014, 50, 11162; (h) Finally, we would like to thank Dr. Rachel Schurhammer (UMR Zhang, C.; Wang, Q.; Long, H.; Zhang, W. J. Am. Chem. Soc. 2011, 7140, Laboratoire de chimie de l'état solide) for helpful discus- 133, 20995; (i) Hong, S.; Rohman, M. R.; Jia, J.; Kim, Y.; Moon, D.; sions about molecular modelling.

\section{REFERENCES}

Kim, Y.; Ko, Y. H.; Lee, E.; Kim, K. Angew. Chem. Int. Ed. 2015, 54,13241

(8) Kocher, L.; Durot, S.; Heitz, V. Chem. Commun. 2015, 51, 13181 .

(1) (a) Vriezema, D. M.; Comellas Aragonès, M.; Elemans, J. A. A. (9) Ballester, P.; Claudel, M.; Durot, S.; Kocher, L.; Schoepff, L.; W.; Cornelissen, J. J. L. M.; Rowan, A. E.; Nolte, R. J. M. Chem. Heitz, V. Chem. Eur. J. 2015, $21,15339$.

Rev. 2005, 105, 1445; (c) Caulder, D. L.; Raymond, K. N. Acc. (10) Candelon, N.; Lastecoueres, D.; Diallo, A. K.; Ruiz Aranzaes, Chem. Res. 1999, 32, 975; (e) Rebek, J., Jr. Acc. Chem. Res. 2009, J.; Astruc, D.; Vincent, J.-M. Chem. Commun. 2008, 741.

42, 1660; (g) Chakrabarty, R.; Mukherjee, P. S.; Stang, P. J. Chem. (11) (a) Cohen, Y.; Avram, L.; Frish, L. Angew. Chem. Int. Ed. 2005, Rev. 2011, 111, 6810; (j) Harris, K.; Fujita, D.; Fujita, M. Chem. 44, 520; (b) Avram, L.; Cohen, Y. Chem. Soc. Rev. 2015, 44, 586. Commun. 2013, 49, 6703; (k) (m) Smulders, M. M. J.; Riddell, I. A.; (12) Chwalek, M.; Auzely, R.; Fort, S. Org. Biomol. Chem. 2009, 7, Browne, C.; Nitschke, J. R. Chem. Soc. Rev. 2013, 42, $1728 . \quad 1680$. (5) (a) Croué, V.; Goeb, S.; Szalóki, G.; Allain, M.; Sallé, M. (2) (a) Fiedler, D.; Leung, D. H.; Bergman, R. G.; Raymond, K. N. Angew. Chem. Int. Ed. 2016, 55, 1746; (b) Stojanovic, S.; Turner, D. Acc. Chem. Res. 2005, 38, 349; (b) Yoshizawa, M.; Klosterman, J. A.; Share, A. I.; Flood, A. H.; Hadad, C. M.; Badjic, J. D. Chem. K.; Fujita, M. Angew. Chem. Int. Ed. 2009, 48, 3418; (c) Wiester, M. Commun. 2012, 48, 4429; (c) Pochorovski, I.; Diederich, F. Acc. J.; Ulmann, P. A.; Mirkin, C. A. Angew. Chem. Int. Ed. 2011, 50, Chem. Res. 2014, 47, 2096.

114; (d) Leenders, S. H. A. M.; Gramage-Doria, R.; de Bruin, B.; (6) Durot, S.; Taesch, J.; Heitz, V. Chem. Rev. $2014,114,8542$.

Reek, J. N. H. Chem. Soc. Rev. 2015, 44, 433; (e) Rebilly, J.-N.; (7) (a) Zhu, B.; Chen, H.; Lin, W.; Ye, Y.; Wu, J.; Li, S. J. Am. Colasson, B.; Bistri, O.; Over, D.; Reinaud, O. Chem. Soc. Rev. Chem. Soc. 2014, 136, 15126; (b) Zhang, J.; Zheng, X.; Jiang, R.; 2015, 44, 467; $\quad$ (f) Zarra, S.; Wood, D. M.; Roberts, D. A.; Yu, Y.; Li, Y.; Liu, H.; Li, Q.; Shuai, Z.; Li, Y. RSC Adv. 2014, 4, Nitschke, J. R. Chem. Soc. Rev. 2015, 44, 419; (g) Kim, D. S.; 27389; (c) Taesch, J.; Heitz, V.; Topic, F.; Rissanen, K. Chem. Sessler, J. L. Chem. Soc. Rev. 2015, 44, 532; (h) Assaf, K. I.; Nau, Commun. 2012, 48, 5118; (d) Ding, H.; Wu, X.; Zeller, M.; Xie, Y.; W. M. Chem. Soc. Rev. 2015, 44, 394; (i) Otte, M. ACS Catal. 2016, Wang, C. J. Org. Chem. 2015, 80, 9360; (e) Hajjaj, F.; Tashiro, K.; 6,6491

Nikawa, H.; Mizorogi, N.; Akasaka, T.; Nagase, S.; Furukawa, K.; (3) (a) Han, M.; Michel, R.; He, B.; Chen, Y.-S.; Stalke, D.; John, Kato, T.; Aida, T. J. Am. Chem. Soc. 2011, 133, 9290; (f) Rogers, L.; M.; Clever, G. H. Angew. Chem. Int. Ed. 2013, 52, 1319; (b) Burke-Murphy, E.; Senge, M. O. Eur. J. Org. Chem. 2014, 2014, Corbellini, F.; Knegtel, R. M. A.; Grootenhuis, P. D. J.; Crego- 4283; (g) Ding, H.; Meng, X.; Cui, X.; Yang, Y.; Zhou, T.; Wang, Calama, M.; Reinhoudt, D. N. Chem. Eur. J. 2005, 11, 298; (c) C.; Zeller, M.; Wang, C. Chem. Commun. 2014, 50, 11162; (h) Busseron, E.; Lux, J.; Degardin, M.; Rebek, J., Jr. Chem. Commun. Zhang, C.; Wang, Q.; Long, H.; Zhang, W. J. Am. Chem. Soc. 2011, 2013, 49, 4842; (d) Berryman, O. B.; Sather, A. C.; Lledó, A.; 133, 20995; (i) Hong, S.; Rohman, M. R.; Jia, J.; Kim, Y.; Moon, D.; Rebek, J., Jr. Angew. Chem. Int. Ed. 2011, 50, 9400; (e) Liu, M.; Kim, Y.; Ko, Y. H.; Lee, E.; Kim, K. Angew. Chem. Int. Ed. 2015, Yan, X.; Hu, M.; Chen, X.; Zhang, M.; Zheng, B.; Hu, X.; Shao, S.; 54, 13241.

Huang, F. Org. Lett. 2010, 12, 2558.

(4) (a) Branda, N.; Grotzfeld, R. M.; Valdes, C.; Rebek, J., Jr. J. Am Chem. Soc. 1995, 117, 85; (b) Löffler, S.; Lübben, J.; Krause, L.; (9) Ballester, P.; Claudel, M.; Durot, S.; Kocher, L.; Schoepff, L.; Stalke, D.; Dittrich, B.; Clever, G. H. J. Am. Chem. Soc. 2015, 137, Heitz, V. Chem. Eur. J. 2015, $21,15339$.

1060; (d) Mendez-Arroyo, J.; Barroso-Flores, J.; Lifschitz, A. M.; (10) Candelon, N.; Lastecoueres, D.; Diallo, A. K.; Ruiz Aranzaes, Sarjeant, A. A.; Stern, C. L.; Mirkin, C. A. J. Am. Chem. Soc. 2014, J.; Astruc, D.; Vincent, J.-M. Chem. Commun. 2008, 741.

136, 10340; (e) Rieth, S.; Wang, B.-Y.; Bao, X.; Badjić, J. D. Org. (11) (a) Cohen, Y.; Avram, L.; Frish, L. Angew. Chem. Int. Ed. 2005, Lett. 2009, 11, 2495; (f) Preston, D.; Fox-Charles, A.; Lo, W. K. C.; 44, 520; (b) Avram, L.; Cohen, Y. Chem. Soc. Rev. 2015, 44, 586. Crowley, J. D. Chem. Commun. 2015, 51, 9042; (i) Kishi, N.; Akita, (12) Chwalek, M.; Auzely, R.; Fort, S. Org. Biomol. Chem. 2009, 7 M.; Yoshizawa, M. Angew. Chem. Int. Ed. 2014, 53, 3604; (j) 1680.

Ajami, D.; Rebek, J., Jr. J. Am. Chem. Soc. 2006, 128, 15038; (k)

Gottschalk, T.; Jaun, B.; Diederich, F. Angew. Chem. Int. Ed. 2007, 46, 260; (m) Hiraoka, S.; Harano, K.; Shiro, M.; Shionoya, M. Angew. Chem. Int. Ed. 2005, 44, 2727; (n) Sørensen, A.; Castilla, A. M.; Ronson, T. K.; Pittelkow, M.; Nitschke, J. R. Angew. Chem. Int. Ed. 2013, 52, 11273 .

(5) (a) Croué, V.; Goeb, S.; Szalóki, G.; Allain, M.; Sallé, M. Angew. Chem. Int. Ed. 2016, 55, 1746; (b) Stojanovic, S.; Turner, D. A.; Share, A. I.; Flood, A. H.; Hadad, C. M.; Badjic, J. D. Chem. Commun. 2012, 48, 4429; (c) Pochorovski, I.; Diederich, F. Acc. Chem. Res. 2014, 47, 2096.

(6) Durot, S.; Taesch, J.; Heitz, V. Chem. Rev. 2014, 114, 8542. 


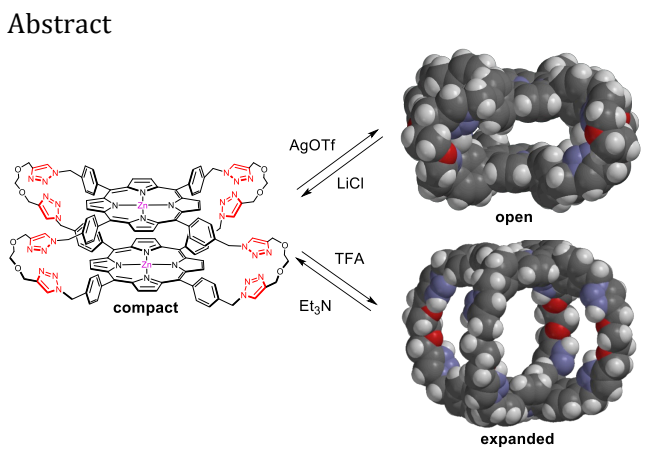

The synthesis of two fl exible bis-porphyrin cages 3 and 4, incorporating respectively Zn(II) porphyrins and free-base porphyrins, is reported. In both cages, the four covalent linkers that bind the two porphyrins are functionalized with two 1,2,3triazolyl ligands. These cages were characterized by NMR and HRMS, and for cage 3 incorporating 1,4- diazabicyclo[2.2.2] octane (DABCO), an X-ray crystallographic structure was obtained. Chemically induced conformational changes are studied and compared to those of two related cages with longer fl exible linkers. Binding of four silver(I) ions to the peripheral ligands opens the $\mathrm{fl}$ attened structures in solution and locks the two porphyrins in a face-to-face disposition. Addition of an excess of acid fully expands the cages due to electrostatic repulsion between the positively charged sites. These two reversible processes allow for a chemically induced breathing of the flexible structures. 